Vegueta. Anuario de la Facultad de Geografía e Historia

21 (1), 2021, 407-441

eISSN: 2341-1112

https://doi.org/10.51349/veg.2021.1.16

\title{
«La Inquisición de Canaria, de poco acá, es un ingenio de azúcar». Oficiales del Santo Oficio en el negocio azucarero
}

\author{
"The Inquisition of Canaria, in Recent Times, is a Sugar Mill". \\ Officers of the Holy Office in the Sugar Business \\ Francisco Fajardo Spínola \\ Universidad de La Laguna \\ https:/ / orcid.org/0000-0003-4098-1985 \\ ffajardo@ull.edu.es
}

Recibido: 27/06/2020; Revisado: 08/11/2020; Aceptado: 20/11/2020

\begin{abstract}
Resumen
El artículo estudia la participación de oficiales de la Inquisición (inquisidores, fiscal, secretario, contador, receptor, alguacil mayor...) en distintas actividades lucrativas que se desarrollaban en torno a la explotación de los ingenios azucareros de Gran Canaria en las primeras décadas del siglo XVII. Esa implicación conllevó conflictos jurisdiccionales, disputas judiciales con determinados vecinos y enfrentamientos entre los propios servidores inquisitoriales; muy lejos todo ello de la imagen que suele tenerse del Santo Oficio, o de la que éste proyectaba acerca de sí mismo. Secundariamente, el trabajo permite conocer distintos aspectos y prácticas del mundo del azúcar, ya en su etapa final en la isla.
\end{abstract}

Palabras clave: Canarias, siglo XVII, Inquisición, corrupción, ingenio de azúcar

\begin{abstract}
This article analyses the participation of officers of the Inquisition (inquisitors, prosecutors, secretaries, contador, receivers, alguacil mayor, etc.) in different lucrative activities revolving around the sugar mills of Gran Canaria during the early decades of the 17th century. This involvement led to jurisdictional conflicts and judicial confrontations with certain neighbours, as well as between the inquisitorial members themselves; all of this a far cry from the prevailing image of the Holy Office, or the one it projected about itself. Secondarily, the paper sheds light on different aspects and practices in the world of the sugar business, already in its final phase on the island.
\end{abstract}

Key words: Canary Islands, Seventeenth Century, Inquisition, Corruption, Sugar Mill. 


\section{INTRODUCCIÓN}

La Inquisición fue, principalmente, una institución de carácter judicial cuyo cometido específico era la investigación y el castigo de las herejías o de otras desviaciones doctrinales conexas con ellas (FAJARDO, 2003). Consecuentemente, la historiografía inquisitorial se ha centrado en el estudio de su actividad procesal en cuestiones de fe; ya en general, ya en determinados territorios, lo mismo tratando sobre el conjunto de los delitos que ocupándose de alguno de ellos en particular. Tanto la inquisición -la pesquisa- como el posterior enjuiciamiento de las transgresiones generaron, lógicamente, una particular tipología documental: testificaciones, procesos, libros de votos, libros de la cárcel, relaciones de las visitas al distrito, relaciones de causas de fe, alegaciones fiscales, etc. La maquinaria represiva exigía una organización, que ha sido de igual manera, en sus distintos aspectos, objeto de investigación: la hacienda inquisitorial, la legislación y la normativa interna, la conformación y funcionamiento de los distintos órganos y jerarquías, los instrumentos de control del propio aparato. Numerosos estudios han explorado el contexto sociológico de los servidores de la Inquisición: extracción social, estudios, carreras profesionales, relaciones personales y de parentela, redes clientelares y vínculos con el poder, desde el espacio central de la corte hasta los ámbitos locales. La protección de todos sus ministros frente a las posibles intervenciones de otros poderes llevó al establecimiento de un fuero privativo para los componentes de la plantilla inquisitorial, sus subalternos y sus familias. De ese modo, los tribunales del Santo Oficio tuvieron bajo su jurisdicción la resolución de los litigios de naturaleza tanto civil como criminal en los que estuviese implicada su propia gente, aunque el asunto en cuestión nada tuviera que ver con la fe (PANIZO, 2014).

Si bien no fue estrictamente el primero en hacerlo, Julio Caro Baroja nos enseñó a ver otras dimensiones de la figura del inquisidor más allá del «carácter apocalíptico» que se le atribuía: el inquisidor como jurista que ha de actuar según la norma, el inquisidor como funcionario y como persona que, como tal, tiene necesidades, ambiciones y debilidades (CARO BAROJA, 1968). Precisamente, mi trabajo se basa -sobre todo- en el estudio de un conjunto de causas civiles (y unas pocas criminales) instruidas por el tribunal de la Inquisición de las islas Canarias en las tres primeras décadas del siglo XVII en las que aparecen implicados varios de sus agentes en litigios que nacieron de conflictos de intereses en torno a la producción azucarera. Constituyen una valiosa fuente para el conocimiento de distintos datos y aspectos de la explotación de los ingenios azucareros en la isla de Gran Canaria en el período final de su existencia; con esa capacidad que tienen a menudo los documentos judiciales para proporcionar una información que no hallamos en los de otra naturaleza. Con todo, nuestras referencias al negocio azucarero serán secundarias, pues sólo se abordará éste en la medida en que en él estén interesados ministros del Santo Oficio y para hacer más comprensible el relato de los asuntos en que los mismos aparecen involucrados.

Algunas de las actividades de estos oficiales se situarían dentro del campo de la corrupción, que ha sido tratada en distintos estudios empleando otras fuentes 
documentales, singularmente, por lo que se refiere al personal inquisitorial, las visitas de inspección a los distritos; $y$, a este respecto, procede señalar la utilidad de unas fuentes poco frecuentadas, las causas que no son de fe. Como bien se ha advertido, conviene no juzgar comportamientos del pasado a partir de nuestros sistemas de valores, de nuestras consideraciones acerca de las fronteras entre lo público y lo privado o de la licitud del enriquecimiento personal en el ejercicio de un cargo; pero es innegable que había una clara conciencia de que determinadas prácticas eran inadecuadas, atentaban contra el bien común y merecían, en consecuencia, un reproche moral y una sanción penal. ${ }^{1}$ Como se verá, en la mayor parte de los casos que estudiamos existió la percepción de que hubo abusos, engaños, utilización de la institución en provecho propio y, en suma, lo que podemos denominar, sin temor al posible anacronismo, corrupción. Otras actividades no podrían ser consideradas propiamente corruptas, pero sí extrañas en hombres del Santo Oficio, y en todo caso ilustrativas de sus ocupaciones y vinculaciones mundanas. Lo cual no es anecdótico, pues para entender cabalmente la actuación de la Inquisición hay que tomar en consideración el contexto territorial, social e institucional en el que se produce, dado que el mismo podía condicionar, y condicionó, el sentido y el alcance de su acción.

La implicación de distintos oficiales inquisitoriales en el cultivo de la caña, su molienda, la obtención y comercialización del azúcar, así como en la financiación de esos procesos dio lugar a conflictos de intereses que hubieron de resolverse ante instancias judiciales, lo que finalmente significaba, dado el carácter privilegiado de su estatus jurídico, ante el tribunal del Santo Oficio. Intentaremos hacer una exposición de los litigios principales en un orden cronológico aproximado y atendiendo a quiénes fueron sus protagonistas, con la observación de que en ocasiones los distintos asuntos se interrelacionan e imbrican hasta el límite de lo laberíntico.

\section{EL CONTADOR CRISTÓBAL CACHUPÍN}

Cristóbal Cachupín Palacios, contador del tribunal canario entre 1603 y 1631 y regidor de Gran Canaria durante parte de esos años, es uno de los personajes importantes cuyos negocios atraviesan todo el período estudiado. En 1601 había solicitado ser receptor de la Inquisición de las islas; ${ }^{2}$ y en 1602 fue nombrado contador de la Catedral, cargo que simultaneó con el de contador del Tribunal. Estas fechas hacen inverosímil la afirmación de Cioranescu de que había nacido en $1585 .^{3} \mathrm{Su}$ función como contador consistía en tomar las cuentas al receptor,

1 Una revisión de la bibliografía y de los debates actuales sobre la cuestión en ANDÚJAR et al. (2017).

2 El 3 de noviembre de 1601 el Consejo de la Inquisición, entonces en Valladolid, ordenó al tribunal canario aceptar la solicitud de Cristóbal de Cachupín para ser nombrado receptor. Archivo Histórico

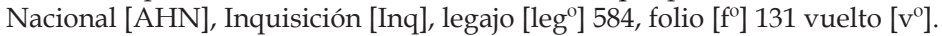

3 Cioranescu (1958: 295) escribe, sin aportar pruebas o referencias, que «sin duda alguna» el jesuita palmero Francisco Cachupín pertenecía a la familia de Cristóbal Cachupín Palacios, nacido en 1585, puede sobreentenderse que -según él- en La Palma. En 1620 Cristóbal Cachupín declaró ante el Tribunal tener 46 años, con lo que su fecha de nacimiento estaría en torno a 1574, Archivo del Museo 
partida por partida, de todos los ingresos y de todos los gastos de la hacienda inquisitorial. ${ }^{4}$ Era uno de los oficiales laicos retribuidos, y como tal sujeto a determinadas exigencias y limitaciones.

Desde 1603, al menos, encontramos a Cachupín dedicado a la producción azucarera. ${ }^{5}$ En 1604 se concertó con Marcos de León, regidor, para que éste le moliera en su ingenio de Telde once suertes de cañas y le proporcionara los oficiales, las casas y todos los medios materiales necesarios para la obtención del azúcar; comprometiéndose Cachupín a pagar una maquila de 700 reales por tarea molida. ${ }^{6}$ Entre las once suertes había dos de una capellanía de Bartolomé López, capellán de la Catedral, que cultivaba a medias con Cachupín. El azúcar no salió bueno, por lo que López en agosto de 1605 se querelló ante el teniente de gobernador, letrado que hacía de juez real, contra Cachupín, considerándolo responsable de la molienda y pidiendo el pago del daño causado; pues, aducía, él no se había concertado con Marcos de León, sino con Cachupín. En la querella se refería a éste como contador de la Catedral y omitía que lo era también de la Inquisición, quizás no queriendo introducirla.

Cachupín alegaba que no tenía él la obligación de pagar los daños a Bartolomé López, sino Marcos de León, como persona que le había molido las cañas; ${ }^{7}$ por lo que, a su vez, se querelló contra el dueño del ingenio ante el Santo Oficio, el cual reclamó la jurisdicción y advirtió a la justicia ordinaria que no procediera en la causa. De León intentó que el Tribunal se inhibiera, alegando tener noticia de que el Consejo de la Inquisición había ordenado que las causas civiles de los oficiales del Santo Oficio se siguieran ante la justicia real, pero los inquisidores declararon que no había lugar a tal pretensión. Según el contador, Marcos de León tuvo la obligación de poner el azúcar en los andamios y furos y beneficiarlo luego haciéndolo purgar sin dilación; y en lugar de esto había tenido el azúcar por los suelos más de tres meses -desde mediados de abril hasta finales de julio- sin purgarlo ni beneficiarlo, con muchísimo daño para el azúcar, «que ha salido todo negro y menoscabado y podrido». ${ }^{8}$ Estimaba en 500 ducados la cantidad perdida,

Canario [AMC], Inquisición [Inq], cxIX-44, $\mathrm{f}^{\circ}$ 52. En las primeras décadas del siglo XVII era notario del secreto de la Inquisición de Valladolid un Sebastián Cachupín Palacios (SÁEnZ, 1998), pero no nos consta una relación con el contador canario.

4 La real provisión por la que se le hacía el nombramiento señalaba como cometidos suyos supervisar y aprobar las cuentas que debía hacer el receptor del cobro y administración de los bienes confiscados, de los censos, juros y rentas de la Inquisición, así como de las propiedades que ésta tuviera en el distrito; haciéndole cargo de todo lo que se le debiere hacer y descargo de lo que hubiere dado y pagado, así en salarios como para otros gastos. Se le asignaba el salario de 20.000 maravedíes anuales. Valladolid, 16 de julio de 1603 . AHN, Inq, libro [lib $\left.{ }^{\circ}\right] 367, f^{\circ} 14$.

5 Aparece en esa fecha explotando a partido el ingenio de Gregorio del Castillo en Telde (TORRES, 1991: 297).

6 «A maquila que es dar dinero el que arrienda a el s[eño]r del ingenio tanta quantidad la que se conciertan por tarea», AHN, Inq, leg ${ }^{\circ} 1815,2, \mathrm{f}^{\circ} 73 \mathrm{v}^{\circ}$. Escritura ante Andrés de Rosales, el 12 de diciembre de 1604, Archivo Histórico Provincial de Las Palmas (AHPLP), Protocolos Notariales (PN) 940, fo 285. Ver en el Anexo documental (11.1) el texto del albalá previo, elevado luego a escritura pública.

7 «Que yo no fui arrendatario de los cañaverales de compañía sino de los mios propios», AHN, Inq, $\operatorname{leg}^{\mathrm{o}} 1815,2, \mathrm{f}^{\mathrm{o}} 112$.

8 AMC, Inq, CLXI-18. Según Cachupín, no lograría vender el azúcar por más de 20 reales por arroba, mientras que si fuera «bueno y de recibir» lo pagarían a 48-50 reales. 
que el propietario del ingenio debería satisfacer.

Marcos de León alegaba que el cañaveral que tenían en compañía Cachupín y Bartolomé López eran una suerte de soca y otra de resoca, y que él se había obligado a moler y hacer beneficiar y purgar cañaverales de planta y de soca, y nada se decía de la resoca; que el Tribunal lo compelió a moler también las resocas, a petición de Cachupín; y que este último hizo que los desburgadores cortasen juntas las cañas de soca y de resoca, y que al ser éstas pequeñas, y con barreno, de esa mezcla nunca podría salir buen azúcar. ${ }^{9}$ Que la costumbre era moler primero las socas, y al final la caña de planta, porque ésta aguantaba mejor; pero que Cachupín hizo moler primero las suertes de planta, en las que sólo él estaba interesado, y dejó para el final las suertes de soca y resoca que tenía en compañía con Bartolomé López, de modo que cuando estas últimas cañas se molieron estaban muy secas y con poca o ninguna sustancia. Continuaba León exponiendo que Cachupín puso los azúcares suyos propios en formas viejas, en que otras veces se habían purgado azúcares, mientras que para el azúcar procedente del cañaveral que tenía en compañía con López hizo que se usaran formas nuevas, de las que normalmente no salen tan buenos los azúcares como en las viejas y usadas, lo que no había sido menor causa para que se dañasen los azúcares. ${ }^{10}$ Negaba León que los azúcares hubiesen estado tres meses en el suelo, afirmaba que habrían estado todo lo más veinte días, que es el tiempo que ordinariamente pasa desde que se llevan del ingenio a las casas de purgar, mientras se preparan andamios para poderlos encabalgar; y sostenía que, de todos modos, no habría habido mayor problema si hubiesen estado más tiempo en el suelo, pues muchas veces pasaban así dos o tres meses, "y han salido blancos buenos y legitimos». ${ }^{11}$ Concluía que el dueño de ingenio «la obligacion $\mathrm{q}[u e]$ tiene es solo a dar maestro esaminado y oficiales suficientes y no a mas y quando algun daño o falta tienen los asucares tiene obligacion a pagarla el maestro que los templo y a el se le pide el daño y no al señor del ingenio». ${ }^{12}$

9 «Que comunmente no se muele sino que se cortan p[ara $]^{a}$ plantar", decía un labrador; «que [...] ordinariam $[e n]^{\text {te }}$ se limpian las calderas con las $\mathrm{d}[i c]$ has resocas, porque si se perdiere la tarea con que limpian el cobre la pr[imer $]^{a}$ ves, no se pierde tanto como si fuese de planta y soca», declaraba un cañaverero, ambos favorables a Marcos de León. AMC, Inq, CL-8, fs. 71 y 79, respectivamente. En este trabajo transcribimos soca y resoca (en lugar de zoca y rezoca), que son las formas con que aparecen esos términos en los documentos consultados.

10 Varios testigos: «demás de ser el asucar [de soca] flaco, la forma nueva le chupa la sustancia que tray, y asi muchos panes no pueden salir bien de las formas por ser nuevas y antes se quiebran»; Juan Suárez de Figueroa, familiar del Santo Oficio, regidor: «que es cosa muy peligrosa echar el açucar en formas nuevas si no es teniéndolas en agua veinte días antes». AMC, Inq, CL-8, fs. $71 \mathrm{v}^{0}$ y $98 \mathrm{v}^{\circ}$, respectivamente. Las Ordenanzas del Concejo de Gran Canaria prohibían remojar formas en las acequias, lo que prueba que eso se hacía (Morales, 1974: 123). En Colombia, en el siglo xx, las formas se mantenían en agua antes de su uso (FIGUeroA, 1963: 577).

11 AMC, Inq, CL-8, fo 6 .

12 Un testigo: que ha visto «muchas veces a el maestre pedir a los señores de las cañas albalá y seguro de los cañaverales que tenia sospecha que no abia de salir buen asucar, y que por estas razones entiende este testigo que el maestre que templa y purga el asucar es obligado a pagar a los señores de los cañaverales el daño». AMC, Inq, CL-8, f 71 v ${ }^{\circ}$. Según Bartolomé Díaz, tachero, escumero y calderero de melar «es costumbre pagar los maestros el daño a seys por siento en solo el asucar blanco». Idem, fo $272 \mathrm{v}^{\mathrm{o}}$. 
Cachupín argüía que bajo el nombre de socas se entiende soca y resoca, pues, de otro modo, resultaría que había de buscar para la planta y soca un ingenio y para las resocas otro; que las socas y resocas estaban muy buenas y limpias al momento de molerse, maduras y sin barreno, de modo que no era atribuible a ellas que el azúcar no saliese bueno. Finalmente, negaba ser cierto que hubiese reservado las formas viejas para el azúcar que le pertenecía en exclusiva, y las nuevas para el que tenía en compañía de López; y, en cualquier caso, rechazaba que el azúcar se perdiera por echarse en formas nuevas, "pues sólo causa a veces tener más o menos lustre el azúcar», que en formas nuevas se han sacado y se sacan azúcares de mucho «estremo» y bondad, y concluía con una evidencia: en algún momento se comienza a purgar en formas nuevas, que acabarán siendo viejas, «pues estas no se perpetuan». ${ }^{13}$

Ante el inquisidor, Pedro Hurtado de Gaviria, o ante Thomás Marín, notario del Santo Oficio en Telde, comparecieron medio centenar de testigos, quienes, como de ellos se esperaba, confirmaron en general las tesis de la parte que los presentaba. Maestros de azúcar, purgadores, caldereros, tacheros, banqueros, escumeros, cañavereros, desburgadores, labradores, camelleros, mercaderes, escribanos, alguaciles ... todo el que tenía o había tenido algo que ver en el ingenio en cuestión, o en el mundo del azúcar en general, dieron sus más o menos autorizadas opiniones. Es de destacar que Marcos de León contó a su favor con destacados elementos de la vida política de la isla, como lo eran los regidores Alonso Venegas, Gaspar de Ayala, Guillén de Ayala y Miguel de Muxica. El propio León, al tachar los testigos de Cachupín por ser, según decía, criados suyos y «hombres bajos», afirmaba que los suyos eran «hombres honrados y los más de ellos muy principales y de mucha calidad, que son personas que han tenido ingenios, molido cañaverales y tienen mucha noticia y experiencia de azúcares». ${ }^{14}$ Cachupín presentaba a León como un hombre poderoso. Bartolomé López venía a insinuar lo mismo al pedir que examinasen el azúcar y determinasen su valor «maestres o personas $\mathrm{q}[\mathrm{ue}]$ lo entiendan $\mathrm{q}[\mathrm{ue}]$ sean sin sospecha, y no de los ordinarios $\mathrm{q}[u e]$ son criados de los $\mathrm{s}[e \tilde{n} o]^{\text {res }}$ de ing[enio $]^{\mathrm{s}}$ de la ciudad de Telde $\mathrm{q}[u e]$ son interesados en esta causa». ${ }^{15}$ En suma, se trataba de establecer «si fue falta de maestro o si fue por ser el $\mathrm{d}[i c]$ ho asucar procedido de cañas de soca y resoca mescladas [...] o si fue de aver estado en el suelo». ${ }^{16}$

Los testigos favorables a Cachupín sostenían que el caldo procedente de la molienda venía en buenas condiciones, ${ }^{17}$ pero que el azúcar había sufrido, una vez en las formas, a causa de no haber sido éstas puestas a su tiempo en andamios. Los dos «entendidos» nombrados por el Tribunal atribuyeron al maestre que había

13 Idem, fo 9.

14 AHN, Inq, $\operatorname{leg}^{\circ} 1815,2$, f 142.

15 Idem, fo 103.

16 Idem, $\mathrm{f}^{\mathrm{o}} 18 \mathrm{v}^{\mathrm{o}}$.

17 Que el azúcar «en caldo en casa de calderas [...] y después de cocido en las formas andaba y anduvo muy bueno y se templaba y templó en las vendas ordinarias en $\mathrm{q}[u e]$ se suelen templar los azúcares y aguardaba y aguardó en el reinchimiento $\mathrm{q}[u e]$ se suele hacer y hace en las formas de manera $\mathrm{q}[u e]$ si se hubiese purgado con la brevedad $\mathrm{q}[u e]$ se debía [...] saliera todo muy bueno», AMC, Inq, CL-8, $\mathrm{f}^{\mathrm{o}} 43 \mathrm{v}^{\mathrm{o}}$ 
purgado los azúcares la responsabilidad en el penoso resultado. Sus dictámenes tienen interés para el conocimiento de la práctica de los ingenios. ${ }^{18}$

El Tribunal falló en 1606 a favor de Bartolomé López, obligando a Cachupín a que lo indemnizara por el daño sufrido por los panes de azúcar. ${ }^{19}$ Pero en 1611 emitió sentencia a favor del contador en su pleito con Marcos de León, a la sazón difunto, condenando a sus herederos a pagar a Cristóbal Cachupín tanto la pérdida sufrida por éste como lo que éste había pagado a López. ${ }^{20}$ Todavía en 1628 los herederos de León pleiteaban en el Consejo contra Cachupín. ${ }^{21}$

El fuero inquisitorial vuelve a proteger al contador Cachupín en 1608, cuando fue denunciado por mandar cortar leña en montes públicos y en propiedades particulares con destino al ingenio que había arrendado en Telde. El teniente de gobernador, Moreno Bohorques, visitó el ingenio, requisó el libro de cuentas de la hacienda, puso guardas para evitar que se consumiese la leña y encarceló a varios de los leñadores; ante lo cual Cachupín declinó la jurisdicción a favor del Santo Oficio. El Tribunal inquisitorial ordenó al juez real y al escribano entregar los autos y el libro, y, como dilataran la entrega y los dieran a la Real Audiencia, excomulgó a ambos, les embargó bienes, los multó y puso preso al escribano. ${ }^{22} \mathrm{~A}$ la Real Audiencia le exigió que se inhibiera, por «ser esta causa de oficial del S[an] to Off $[i c i]^{\circ}$ y privativo el conocimiento dellas de este Tribunal». ${ }^{23}$

Entre la docena de personas presas por mandato de la Real Audiencia, uno de ellos, Manuel Díaz, era familiar de la Inquisición. Propietario de un cañaveral, los testigos lo señalaban también como alguien que con sus esclavos y trabajadores había participado en la destrucción del monte. Se acogió, naturalmente, a la jurisdicción del Tribunal, por lo que los inquisidores mandaron a Francisco de la Cruz, secretario de la Real Audiencia, que entregase los autos de la causa instruida contra Díaz, lo que se apresuró a hacer. Quizás los inquisidores no

18 Esteban de Xerez, mercader, dijo «q[ue] los dhos açucares están muy flacos y mal ayudados y por ser tanta su flaqueza quando se les echo varro prim $[e r]^{\circ}$ se iban todos por vaxo como se ve de los $\mathrm{d}[\mathrm{ic}]$ hos açucares por estar los coguchos todos rendidos y como vido el purgador que se iban por vaxo les quito el varro en fresco y se aguaron los açucares con aquella humedad y no purgaron bien como se ve dellos porq $[u e]$ no hizieron cara $[\ldots]$, y ansi los $\mathrm{d}[i c]$ hos açucares le parece q[ue] no podrán valer sino a precio de veinte o veinte y quatro rs. cada arroba por estar menoscabado y no se poder navegar ni meter en caxas sino abatidos y quebrados, y que [...] fue causa dello el maestro de los d[ic] hos açucares por no haberles hecho los beneficios necesarios y convenientes [...] y no haber cuajado ni purgado bien [...] y aberles dado poca lexía [...]». Andrés Pérez, maestre de azúcares, dijo «que el d[ic] ho açucar [...] tiene mucho daño porque esta muy negro [...] y descoguchado y flaco y poco ayudado y muy blando que no sirve para cargazones por açucar blanco [...] por no haverle ayudado con la lexía como debía templarlo en casa de calderas y después havello echado en formas nuevas y por estar flaco no haver podido sufrir el barro y asi se yba por baxo y le quitaron el barro antes de tpo por que no se acabara de ir por los coguchos». AMC, Inq, CL-8, fs. 186 y ss.; AHN, Inq, leg ${ }^{\circ} 1815,2$, fo 108 y ss. 19 AMC, Inq, CL-8, fo $208 \mathrm{v}^{\mathrm{o}}$; AHN, Inq, $\operatorname{leg}^{\mathrm{o}} 1815,2, \mathrm{f}^{\mathrm{o}} 122 \mathrm{v}^{\mathrm{o}}$.

20 Debían pagar a Cachupín los 1571 reales que éste debió pagar a López; y, además, el daño sufrido por el azúcar de la parte que perteneció a Cachupín y era objeto del pleito. $\mathrm{AHN}, \mathrm{Inq} \operatorname{leg}^{\circ} 1815,2, \mathrm{f}^{\circ}$ 186.

21 AHN, Inq, $\operatorname{leg}^{\circ} 1815,2$.

$22 \mathrm{Al}$ teniente de gobernador le impusieron una multa de 60 ducados, y después de 100 ducados más, le embargaron y subastaron 48 libros de leyes y otros bienes. El escribano, Bernabé Díaz, fue multado en 30 ducados, más otros 50 más tarde, y puesto en la cárcel pública con un par de grillos.

23 AMC, Inq, xxII-14, fo 57. 
fueron tan expeditivos en este caso, pues Díaz pasó un par de semanas en la cárcel pública, y hubo de repetir su demanda, antes de ser entregado al Santo Oficio. Los testimonios recogidos en los autos son un buen exponente de los efectos devastadores de la explotación azucarera; así como, en este caso, de la acción depredadora, posiblemente impune, de oficiales y servidores de la Inquisición. ${ }^{24}$

En febrero de 1610 compareció ante el Tribunal Juan Pérez de Returvio Otañes ${ }^{25}$ pidiendo que se mandase a Cristóbal Cachupín que moliese de inmediato un cañaveral suyo, situado en Telde, que se había obligado el contador a moler en su ingenio, y que lo hiciese antes de moler las cañas de Lorenzo de Zurita, receptor de la Inquisición, y otras del propio Cachupín, que al parecer pensaba moler primero. Aducía Returvio que el suyo no podía esperar, "por estar muy dañado y barrenado de gusano, y cada dia pierde su valor y le urtan ladrones por estar demasiado de maduro». ${ }^{26}$ Pedía que, en caso de que Cachupín no pudiese molerlo enseguida, mandase el inquisidor que lo moliera en su ingenio Rodrigo de León, quien estaba presto a hacerlo sin más tardanza, descargando a Returbio de la obligación de moler en el ingenio de Cachupín. El Tribunal mandó hacer la información correspondiente, en el marco de la cual diversos testigos dijeron distintas cosas y Cachupín alegó que el cañaveral en cuestión no había perdido nada, «por ser planta y estar verde la caña».

Ese mismo año de 1610 el Tribunal hubo de resolver la demanda que ante él interpuso el contador Cachupín contra Lorenzo de Zurita «sobre lo que es deudor de los costos del fruto de planta del cañaveral de Casa Blanca», en Telde, cuya explotación parece que realizaban en compañía, debiéndose moler la caña en el ingenio de Cachupín. Esta vez, dos ministros del Santo Oficio enfrentados entre sí. Para poder fallar en el litigio entre los dos oficiales inquisitoriales, el Tribunal mandó que el licenciado Pedro Ruiz Montañés, cura de la Catedral, fuese a medir las tierras del cañaveral y a valorar los gastos realizados. ${ }^{27}$

En 1622 se querelló Cachupín, siempre ante el Tribunal, por los daños -cifrados en 200 ducados- que a un cañaveral suyo situado en Agaete habían causado unos animales del licenciado Bartolomé Mireles, cura del lugar. Otro cura, el beneficiado de Gáldar, fue encargado de supervisar la tasación de los daños. ${ }^{28}$

Lo que nos interesa subrayar aquí es cómo, invariablemente, se invocaba la jurisdicción de la Inquisición por parte de sus ministros; y cómo sus oponentes intentaban, infructuosamente por lo que conocemos, que la causa se tramitase por otros jueces. No en todos los casos favoreció el Tribunal a los suyos, pero éstos, al parecer, siempre quisieron jugar en casa.

24 AMC, Inq, xxxvI-9, sin fol ${ }^{\circ}$. Ver Anexo documental 11.2.

25 Juan Pérez de Returbio Otáñez sería regidor unos años más tarde (AlEmÁn, 2014).

26 AMC, Inq, xCII-19, fo 2 .

27 AMC, Inq, CLXXIII-65.

28 AMC, Inq, CXLI-8. 


\section{LUIS PERDOMO, GERÓNIMO RATON Y EL SOBRINO DEL INQUISIDOR MESSÍA}

Entre las causas que examinamos sobresalen, por su entidad, duración, complejidad e incluso mutua interrelación, varias en las que están implicados dos personajes: Gerónimo Raton y Luis Perdomo Betancor. Ambos participarían, como se verá, en diferentes negocios entre ellos, lo mismo que con distintos oficiales inquisitoriales. Las operaciones comerciales y financieras en que encontramos comprometidos tanto a estos dos individuos como a los ministros del Santo Oficio no eran, a menudo, simples. Las características de la economía de la época, quizás en mayor medida en Canarias por la eventual escasez de numerario, hacían que muchos pagos se hiciesen en especie, y que el cobro de ciertas deudas se intentase hacer con cargo a otras deudas en las que el deudor fuese acreedor. Los tratos entre Raton y Perdomo resultan de lo más complicado, no ya porque a veces es uno deudor del otro y otras veces acreedor, sino porque ambas condiciones pueden sumarse y encabalgarse: uno le debe algo al otro al tiempo que el otro le debe por otro concepto al uno. A esto se añadía la cesión, total o parcial, de deudas a terceras personas, así como la escrituración de transacciones -ventas, créditos- fingidas. Ello daba lugar a un laberinto de relaciones difícil de esclarecer; y, desde luego, de imposible exposición aquí. Intentaremos hacer referencia a los más importantes de esos asuntos sin perder de vista cuáles son nuestros objetivos: el estudio de la implicación del personal inquisitorial y la contribución al conocimiento de algunos aspectos de la producción azucarera en el archipiélago.

Gerónimo Raton era, por lo que sabemos, natural de Brujas (BRITo, 2002; MARTín, 2013). En una declaración de 1620 ante el tribunal de la Inquisición se presentaba como mercader vecino de Las Palmas, decía tener 49 años, firmaba Geronimo Ratton y se le daba el tratamiento de capitán generalmente usado para personas de una cierta consideración. ${ }^{29}$ Debía de llevar poco tiempo en la isla. ${ }^{30} \mathrm{En}$ 1618 perdió a manos de corsarios berberiscos, frente a Cádiz, dos navíos cargados de mercancías, sobre todo azúcar, que enviaba a Nápoles. Todo ello había sido muy notorio, porque fueron capturados y llevados a Argel muchos vecinos de la isla, algunos de ellos bien conocidos. ${ }^{31}$ Raton quedó arruinado, según muchos testimonios, lo que hacía dudar de que fueran veraces algunos de los documentos mercantiles que más tarde suscribiría; aunque su boda con María de Franquis, hija del difunto Nicolao de Franquis, genovés, productor de azúcar, que había sido regidor, quizás sustentara de algún modo sus actividades. ${ }^{32}$ Raton debió de

\footnotetext{
29 AMC, Inq, CxIX-44, fo 42. Declaración de 28 de noviembre de 1620. Escribiremos Raton, tal como viene nombrado en todos los documentos examinados.

30 Así se infiere de una declaración suya ante el Tribunal. Idem, $\mathrm{f}^{\circ} 42$.

31 Los testigos mencionan al licenciado Lucas Barreto, «que con una bala le llevaron un brazo», y a Fr. Melchor de Zúñiga, AMC, Inq, xx-12, fs. 484 y 478. Este último, que había sido guardián del convento franciscano de La Laguna (INCHAURBE, 1966: 23), es el autor de la Descripción i República de la Ciudad de Arjel, manuscrito citado por los especialistas en el tema de los cristianos cautivos, Biblioteca Nacional de España, Mss/3227. Ignoramos si eran conocidas las circunstancias y fecha de su cautiverio.

32 «Con cuya perdida quedo mui pobre y fallido [...] y con esto perdio el credito [...] en estas yslas en razon del trato de mercader y asi tiene por cierto este $\mathrm{t}[e s t i g]^{\circ}[\ldots]$ que si $[\ldots]$ se obligo despues de $\mathrm{d}[i c]$
} 
morir en la primera mitad de 1623, por lo que se desprende de la documentación inquisitorial (ya había muerto en julio de ese año).

Luis Perdomo Betancor tomó en arrendamiento para los años de 1617 a 1623 la hacienda del ingenio de Arucas, rico mayorazgo que pertenecía a don Martín Cerón de Santa Gadea, y en calidad de tal, o como consecuencia posterior de su actuación al frente de ella aparece en la documentación consultada. Hubo un período inicial de dos años en los que parece -por declaraciones de testigos- que Perdomo fue socio de Rodrigo Messía (o Mexía), sobrino del inquisidor Gonzalo Messía Lobo (1611-1623), en la explotación del ingenio, aunque en la escritura de arrendamiento sólo figuraba Perdomo; y otro período de cuatro años en que éste estaría solo. ${ }^{33}$ Sabemos muy poco de Luis Perdomo. Cuando, en pleito con Messía, le convino a éste probar que Perdomo no era labrador, se preguntó a los testigos si no era cierto que antes de que arrendase el ingenio vivía «de vender vino y dar de comer en su casa a pasajeros y otras gentes». ${ }^{34} \mathrm{Su}$ condición de analfabeto hace quizás más sorprendente que estuviera al frente de una hacienda tan importante.

En 1619 Luis Perdomo vendió a Gerónimo Raton 400 arrobas de azúcar -a 40 reales por arroba-, procedentes del ingenio de Arucas. Se las entregó «en confianza», Raton «las navegó en su navío fuera desta isla [...] y ahora [...], aunq[ue] le pide q le pague el importe de esas arrobas, no lo hace, ni lo reconoce $\mathrm{p}[o] \mathrm{r}$ señor de ellas», manifestaba ante la justicia el primero. ${ }^{35}$ Mas, para entonces, ya el gobernador había mandado embargar y «poner de manifiesto» esa cantidad de azúcar en manos de Raton como bienes de Perdomo, a instancias de doña Blanca Amoreto, viuda de Lorenzo Guesquier, regidor, para que de ella fuese pagada una deuda contraída por Perdomo. ${ }^{36}$ Raton reconoció haber recibido las 400 arrobas, sin decir de manos de quién; pero unos días más tarde firmó una escritura por la que se obligaba a pagar los 16.000 reales correspondientes a Rodrigo Messía, por cuya orden, decía, le había sido entregado el azúcar en el ingenio de Arucas. Añadía que Rodrigo Messía había sido socio de Perdomo durante dos años en el arrendamiento del ingenio, por lo que, «siendo comp $[a \tilde{n} e r]^{\circ}$ suyo era parte legítima $\mathrm{p}[\mathrm{ara}]^{\mathrm{a}}$ cobrar y vender los $\mathrm{d}[\mathrm{ic}]$ hos frutos». ${ }^{37}$

Don Rodrigo, sobrino como hemos dicho del inquisidor, era socio de su tío en algunos negocios y seguramente testaferro suyo en otros. Que detrás de algunas de estas operaciones estuviese don Gonzalo Messía debe ser más que una suposición, si hemos de creer en ciertos testimonios. Sebastián Farias, maestro de azúcar por entonces en el ingenio de Arucas, aseguró que sabía, «por averlo visto

\footnotetext{
ha perdida a pagar algunas cantidades fue simulado, porque [...] asta que murio estubo [...] muy pobre por cuya causa se fue a vivir a la $\mathrm{v}[\mathrm{ill}]^{\mathrm{a}}$ de Guía para poder pasar con algunas tierras que le dieron en dote con Doña M[ari $]^{\text {a }}$ Franquis su mujer». Declaración de Francisco Gallegos, escribano público, ante la Inquisición, 3 de julio de 1629. AMC, Inq, xx-12, fo 478. Según Andrés Rosales, escribano públiCo, «no se le conoc[ían] en esta isla bienes ningunos excepto el trato que trujo quando a esta isla vino», idem, $\mathrm{f}^{\mathrm{o}}$ 477. Su matrimonio tuvo lugar el 27 de julio de 1620 (MARTín, 2013).

33 Vid. notas 91 y 94.

34 AMC, Inq, LxXII-6, fo 89

35 Demanda presentada ante el gobernador el 19 de agosto de 1619, AMC, Inq, xCVIII-14, fo 1.

36 Auto del gobernador Fernando de Ossorio de 2 de agosto de 1619. Idem, $\mathrm{f}^{\circ} 24 \mathrm{v}^{\circ}$.

37 Ante Juan de Quintana, escribano público, el 3 de septiembre de 1619. AMC, Inq, xx-12, fo 528.
} 
y pasado por sus manos [...] que el entregar estas arrobas de asucar el $\mathrm{d}[i c]$ ho Luis Perdomo al d[ic]ho Geronimo Raton fue en virtud de un papel que el S[eñ $]^{\text {or }}$ Inqq[uisid] ${ }^{\text {or }}$ Messía Lobo le remitió de su firma y letra para que se las entregase, al qual y su fecha y firma se remite».$^{38}$ Otro testigo bien informado, Juan Ángel Poggio, decía que «el s[eñ $]^{\text {or }}$ inquisidor Mexia Lobo y don Rodrigo Mex[í] $]^{\text {su }}$ su sobrino todo es una mesma cosa». ${ }^{39}$ Ya se verán algunas intervenciones de don Gonzalo a propósito de la hacienda de Arucas.

El gobernador mandó a Gerónimo Raton que, con independencia del embargo, pagase a Luis Perdomo el valor del azúcar en cuestión y lo puso preso; el proceso pasó en apelación a la Real Audiencia, la cual confirmó el auto del juez ordinario. ${ }^{40}$ Pero, finalmente, Raton no pagó a doña Blanca, mientras que el documento de depósito del azúcar de Perdomo en manos de Raton desapareció cuando la causa pasó a la Inquisición, como más adelante se repetirá. ${ }^{41}$

Después argumentaría Gerónimo Raton, como otra prueba de que no debía las 400 arrobas de azúcar a Perdomo, que éste nunca había intentado descontar su importe de las deudas que con posterioridad había contraído con él. ${ }^{42}$ Porque, en efecto, aunque el pleito entre ellos continuaba, los negocios también. En abril de 1620, Perdomo admitía deber a Raton, y se obligaba a pagar en septiembre de ese año 7.000 reales, resto de una deuda de 10.116 que reconocía haber recibido de Raton para la fabricación de ese año. Hipotecaba especialmente la cosecha de azúcar, que se comprometía a no vender hasta no haber pagado, pero confesaba haber hecho escritura a favor del capitán Mateo Delgado de seis mil y tantos reales con la misma hipoteca. ${ }^{43}$ La memoria de las partidas suministradas por Raton comienza a finales de agosto de 1619 y llega hasta abril de 1620, con las cuales -decía Perdomo- «he ido moliendo pagando costos y gastos y sustentando la gente del $\mathrm{d}[i c]$ ho ingenio». Las cuentas tienen interés, por cuanto muestran en gran parte los costes de explotación del ingenio y el modo de financiarlos. Raton había adelantado repetidamente cantidades en metálico y pagado la compra, mes tras mes, de alimentos, telas o productos para el ingenio. Había pagado trabajos o servicios (carpinteros, cortadores de madera, acarreadores de caña, camelleros, moledores, aserradores y escribanos), aunque sin duda no están en esta memoria todos los salarios y estipendios que se tuvieron que satisfacer. Pagó tributos, de aquellos con los que la hacienda estaba cargada; así como deudas: entre ellas, 1435 reales que Perdomo debía a Gaspar Álvarez de Miranda, secretario de la Inquisición y que había dado lugar a embargo, según una sentencia del Tribunal. ${ }^{44}$

38 AMC, Inq, xx-12/ cxI-10, fo $510 \mathrm{v}^{\mathrm{o}}$.

39 AMC, Inq, $x x-12, f^{\circ} 425$. Comerciante de origen genovés, Juan Ángel Poggio se asentaría más tarde en La Palma. Es el padre del escritor Juan Bautista Poggio Monteverde.

40 AMC, Inq, xx-12/ cxI-10, fo 510.

41 Así lo declaraba Vicente Álvarez Travieso, pagador de la gente de Guerra, segundo marido de doña Blanca Manrique (o Amoreto), quien añadía que Luis Perdomo se quejaba «del agravio que le habian hecho». AMC, Inq, xx-12/ cxI-10, fo 510.

42 Declaración de Geronimo Ratton ante la justicia real, en el pleito por las 400 arrobas de azúcar, 25 de octubre de 1621. AMC, Inq, xCvIII-14, fo $22 \mathrm{v}^{\circ}$.

43 Escritura ante el escribano Francisco Delgado Salazar en 20 de abril de 1620. AMC, Inq, CXx-19.

44 «Recibí del cap[itán] G[eróni]mo Raton, $\mathrm{m}[e] \mathrm{r}[\mathrm{ca}] \mathrm{d}[e] \mathrm{r}$ estante en la isla, $1430 \mathrm{r}[$ reale $]$ s, en contado

[...]. Este feniquito le sirva al d $[i c]$ ho [Luis Perdomo] para la cantidad por que le tengo executado». 
En enero de 1620 Luis Perdomo reconoció ante escribano público haber recibido «del capitán» Mateo Delgado 6.341 reales en diferentes mercadurías para «la fabricasion de la molienda deste año y demás beneficio de la $\mathrm{d}[i c]$ ha hasienda» -términos habituales-, comprometiéndose a pagarlos en agosto de ese año e hipotecando para ello sus bienes. ${ }^{45}$ Las mercancías adelantadas eran sobre todo productos textiles de todo tipo, junto con otros objetos, lo que hace pensar que Perdomo, además de emplearlos en el ingenio, sobre todo los usaría para negociar con ellos. ${ }^{46}$ La suma de las dos deudas (10.116 reales que debía a Raton más 6.341 reales que adeudaba a Delgado) se elevaba a 16.457 reales, cantidad que Perdomo recibió en dinero o en mercancías el año de 1620. No todo debía de ser imputable a la explotación del ingenio; ni tampoco deben de estar contenidos en esas relaciones todos los costos del mismo.

Gerónimo Raton cedió y traspasó una parte de la deuda de los 7.000 reales a Rodrigo Messía, hasta la cantidad de 5169 reales que al parecer le debía. Es decir, que Messía se constituía en acreedor de Perdomo, sobre cuyos bienes solicitó embargo y ejecución, como así decretó el teniente de gobernador. ${ }^{47}$ Messía acusó a Perdomo de ocultar bienes, pidiendo que los maestros de azúcar y purgadores que había tenido en 1620 y 1621 exhibiesen los libros que tenían obligación de tener, y que de igual modo se mandase sacar de los libros decimales las partidas de los frutos que había diezmado el ingenio, de tal modo que pudiese saberse cuál había sido su producción. ${ }^{48}$ Perdomo continuaría sosteniendo que la deuda de 16.000 reales que decían deber Gerónimo Raton a Rodrigo Messía, era fingida, y así no había fundamento para que Messía le reclamase nada a Perdomo por supuestas deudas de éste con Raton, que también negaba; e insistía en que Raton estaba condenado en esa cantidad. ${ }^{49}$

Fueran las cosas como fueran, Luis Perdomo fue llevado a la cárcel, donde pasaría, con intermitencias, bastantes años, primero por mandato de la justicia real, y luego de la Inquisición.

\section{EL FISCAL GABRIEL MARTÍNEZ PASTOR CONTRA GERÓNIMO RATON}

En diciembre de 1619 interpuso ante el tribunal del Santo Oficio su fiscal, Gabriel Martínez Pastor, una demanda por la que reclamaba a Gerónimo Raton 12.000 reales de plata que le había prestado en La Palma a través del flamenco Juan Pezón..$^{50}$ El licenciado Martínez Pastor fue racionero, arcediano de Fuerteventura

13 de septiembre de 1619. Firma: Gaspar Alv[are]z de Miranda. Era el valor de 52 arrobas de azúcar embargadas. AMC, Inq, xxIII-28, $\mathrm{f}^{\mathrm{O}} 2$.

45 AMC, Inq, CLXxIV-50.

46 Más del 80\% de esos 6.341 reales correspondía a textiles.

47 Auto de Alonso Moratalla Tévar de 29 de julio de 1621. AMC, Inq, Cxx-20, fo 12.

48 AMC, Inq, LxxxvIII-18. 20 de septiembre de 1621.

49 Ante Luis Truxillo Ossorio, juez de la causa, 14 de diciembre de 1621. AMC, Inq, LXXII-6, f 123 vo

50 Todo es más enredado: los 12.000 reales de plata le habían sido entregados a Pezon por el licenciado Sebastián de Sosa, beneficiado de La Palma, por orden de Martínez Pastor, en virtud de una letra suya. 
y prior de la Catedral; y durante un cuarto de siglo servidor del Santo Oficio como abogado de presos, consultor (1608-1611), fiscal (1611-1625) e inquisidor (16251628). Aunque de origen peninsular (era natural de Calahorra), su larga estancia en las islas (desde finales del siglo XVI) le habría permitido penetrar en los círculos sociales y de negocio del archipiélago.

El inquisidor, Franco de Monroy, ordenó el embargo de los bienes de Raton hasta la cuantía reclamada; y éste señaló como bienes de los que cobrarse mercancías suyas que había enviado para su venta a Francisco Lorenzo, un mercader francés residente en Lanzarote, más las deudas que el galo tenía con Raton. Unos días después, Martínez Pastor manifestó al inquisidor que sabía que Gregorio Méndez Pedrosa, dueño del ingenio de Guía, era deudor a Raton de 10.000 reales; y que asimismo Luis Perdomo, arrendador del ingenio de Arucas, le era deudor de más de 3000 reales. Por ello pidió, y así lo mandó el inquisidor, que se tuvieran "por nombrados los $\mathrm{d}[i c]$ hos trese mil reales», para poder ser pagado con cargo a ellos, y que tanto Méndez como Perdomo se constituyeran en depositarios de las respectivas cantidades. ${ }^{51}$ Luis Perdomo reconoció la deuda con Gerónimo Raton pero dijo que no sabía la cantidad líquida, por habérsela dado en muchas partidas de géneros y mercadurías. ${ }^{52}$

Raton debió de quedar arruinado después de la pérdida de sus barcos, o al menos sin crédito ni liquidez. Como muchas de las mercancías las había adquirido a crédito, los azúcares estaban sin pagar y había pedido dinero prestado, una nube de acreedores, además del fiscal, le cayeron encima. Al morir Gerónimo en 1623, éstos activaron la reclamación de sus deudas ante el teniente de gobernador; pero Martínez Pastor alegó que las demandas y ejecuciones debían dirigirse al tribunal de la Inquisición y la justicia ordinaria inhibirse, de modo que el pleito, en efecto, se siguió ante el Santo Oficio. El inquisidor Messía Lobo mandó hacer ejecución de la deuda en los bienes de Raton, que eran -a salvo lo que pudiera constituir la dote de su mujer- cuantiosos. ${ }^{53}$

El inquisidor Gonzalo Messía Lobo era también acreedor del mercader flamenco junto con su sobrino, Rodrigo Messía. Pero no sólo eran jueces y partes los oficiales del Santo Oficio, sino además partes enfrentadas entre sí. La deuda de Gerónimo Raton con Martínez Pastor constaba por un albalá simple firmado ante el secretario del Tribunal, Gaspar Álvarez de Miranda -otro personaje de este enredo-, quien no había recibido comisión para ello. Basándose en la debilidad de ese documento, otros acreedores intentaron ser preferidos a la hora de cobrar

AMC, Inq, $x x-12, \mathrm{f}^{\circ} 1$.

51 Idem, fo 18,24 de diciembre de 1619.

52 Idem, fo 19,3 de enero de 1620.

53 AMC, Inq, xx-12, fo 21. Auto de 30 de julio de 1623. El alguacil del Santo Oficio embargó como suyos los siguientes: «el cañaveral de soca de La Ladera tras el inxenio, la meta de la ladera de soca q[ue] tiene con Luis Barreto y sus herederos, el cañaveral de planta de La Masiega [...] y otro pedaso en Las Palmas [...], el cañaveral de planta en La Longuera, junto a Galdar, el cañaveral de planta en El Drago, $\mathrm{q}[u e]$ tiene de medias con X[ristó]bal de Cachupin, otro cañaveral de planta en Las Palmas en la vega de Galdar, catorze $\mathrm{f}[$ anega $]$ s de $\mathrm{t}[\text { ierr }]^{\mathrm{a}}$ de pan sembrar en Taraçona, termino de Guia, el cuarto de biña $\mathrm{q}[u e]$ tienen los herederos de Gonzalo Trujillo[...]». Además, las casas de su morada en Guía; «unas casas altas y bajas [...] en la calle que sale de los ynoveses», en la ciudad; 238 panes de azúcar que estaban en el ingenio de Guía; dos esclavos; animales, cascos de vino, etc. 
la deuda; entre ellos, y a la cabeza de ellos, el inquisidor Messía Lobo. Todos exhibían escrituras hipotecarias otorgadas ante escribano público, que tendrían mayor fuerza. Pero, según el fiscal y quienes lo apoyaban, esas deudas eran fingidas. Así lo declaraba Bernardino de Serpa, notario de secuestros, en un interrogatorio de testigos presentado en 1629 por Martínez, ${ }^{54}$ que a la sazón había ascendido y había pasado a ser inquisidor; y de la misma opinión era Cristóbal Cachupín, quien igualmente se alineaba con él ${ }^{55} \mathrm{El}$ inquisidor Martínez pleiteaba entonces en interés propio ante el tribunal del que formaba parte.

Cristóbal Cachupín había tenido cañaverales en compañía con Gerónimo Raton. Fallecido éste, y embargados sus bienes, el contador, como parte, y el inquisidor Martínez, como acreedor de Raton, los dieron en explotación de medias; según el hijo de Raton, sin licencia del Tribunal. ${ }^{56}$

En 1624 el licenciado Messía Lobo, a la sazón nombrado para la Inquisición de México, pero presente todavía en Las Palmas, recusaba al inquisidor Santalis en el pleito de acreedores con el fiscal Martínez Pastor: «porque en esta causa le tengo por odioso y sospechoso». ${ }^{57}$ Alegaba que Santalis le debía dinero al fiscal; $\mathrm{y}$, asimismo, que en la casa en que se alojaba se servía de muebles del abogado de una de las partes interesadas. Santalis aceptó inhibirse, no sin manifestar que, si Messía lo recusaba, era porque sabía de sus manejos, y en particular que la escritura de obligación que Gerónimo Raton había hecho en 1623 ante escribano a favor de Messía era un fraude a los demás acreedores, pues se había otorgado siendo el dicho Messía juez en el pleito de acreedores.

Hasta 1630 no llegó la sentencia de la causa que durante tantos años había seguido Gabriel Martínez Pastor, entonces inquisidor y prior de la Catedral, contra Gerónimo Raton y luego Pedro Raton su hijo y heredero, a la que salieron por terceros opositores ocho acreedores más, todos ellos peleando por ser preferidos a la hora de cobrar. El inquisidor visitador Juan de Escobar del Corro, que hizo de juez, graduó a los acreedores, colocando en primer lugar a la viuda de Raton, doña María de Franquis, para que recuperase las 2.465 doblas que había llevado como dote, pero esa suma se la había cedido al inquisidor Martínez -en lo que debió de ser otra trapacería-; como también le había cedido su deuda la acreedora que aparecía en segundo lugar; la deuda con Martínez -los 12.000 reales- aparecía algo

\footnotetext{
54 «En q[uan] to a las deudas que despues desto se contrageren con el $\mathrm{d}[i c]$ ho [Raton], tiene para si por cierto este $\mathrm{t}[\mathrm{estig}]^{\circ}$ serian simuladas y fingidas, porq el $\mathrm{d}[\mathrm{ic}]$ ho Raton no podía pagarlas y en particular sabe este $\mathrm{t}[e s t i g]^{\circ}$ que la deuda por escritura que hizo al sr. Inquisidor Messia Lobo fue simulada y fingida [...] y el S[eño]r Inquisidor Messia Lobo le dijo a este $t[e s t i g]^{\circ}$ que Raton le avia de hazer una escritura de quatro mil y tantos reales para ser anterior a la deuda del S[eño]r Inqq[uisido]r Martínez por quanto estaba por sedula y no por escritura por lo qual este $\mathrm{t}[\mathrm{estig}]^{\circ}$ conosio ser mal trato pues no pudiendo pagar dose mil reales se obligava a pagar la cantidad dicha, y ansimismo este $\mathrm{t}[\mathrm{estig}]^{\mathrm{o}}$ tiene $\mathrm{p}[o] \mathrm{r}$ cierto que las arras $\mathrm{q}[u e]$ el $\mathrm{d}[i c]$ ho [Raton] prometio a doña $\mathrm{M}^{\mathrm{a}}$ Franquis su mujer y la deuda de $\mathrm{Ju}^{\circ}$ Angel Pogio y la referida del S[eño]r Inquisidor Messia Lobo no las pudo prometer ni contraer por estar como ha dicho fallido y quebrado». AMC, Inq, xx-12, fo 481.

55 «De lo qual se colige serian simuladas [las otras deudas] porque el d[ic]ho S[eño]r Inq[uisido]r [Martínez] no cobrase». Idem, $\mathrm{f}^{\circ} 484 \mathrm{v}^{\circ}$

56 AMC, Inq, xxI-7, 18 de julio de 1626.
}

$57 \mathrm{AHN}$, Inq, leg ${ }^{\circ}$ 1814, 6 E. Escrito de 27 de junio de 1624. 
después; «a la p $[\text { ar }]^{\text {te }}$ del inq[uisido]r Messia Lobo»-ya fallecido- ${ }^{58}$ se le reconocían 4.640 reales (de 16.000 que inicialmente había reclamado, pero había sido pagado en parte); también cobraría el mencionado Juan Ángel Poggio; y al final de todos, el noveno, Luis Perdomo, la gran víctima: «de los demás bienes $\mathrm{q}[u e]$ quedaren, pagados los $\mathrm{d}[i c]$ hos acreedores se paguen a Luis Perdomo Betancor diez y seis mil r $[e a l e] \mathrm{s} \mathrm{q}[u e]$ parece haver montado el precio de quatrocientas y seis arrobas de açucar $\mathrm{q}[u e]$ le vendio al $\mathrm{d}[i c]$ ho Geronimo Raton». ${ }^{59}$ Perdomo, como se ha dicho, había obtenido sentencia de la justicia ordinaria a su favor, confirmada por la Real Audiencia; pero el pleito, que pasó al Santo Oficio, desapareció, al parecer en las manos de Bernardino de Serpa, notario de secuestros del Tribunal. Este último, a falta de esos documentos que desaparecieron, mandó colocar a Luis Perdomo al final de la lista de acreedores de Gerónimo Raton, cuando debió ser el primero, porque, como alegaba en su apelación ante el Consejo de la Inquisición, su deuda era anterior a todas las demás, "por ser hecha antes de que el $\mathrm{d}[i c]$ ho Hier[óni] ${ }^{\text {mo }}$ Raton contrajese matrim [oni $]^{\circ}$ con doña $\mathrm{M}^{\mathrm{a}}$ de Franquis y antes mucho tiempo que se plantasen los cañaverales que puso el dho Hier[óni] ${ }^{\text {mo }}$ Raton en la villa de Guía». ${ }^{60}$ Posiblemente, nunca cobró.

\section{EL SECRETARIO ÁLVAREZ DE MIRANDA CONTRA LUIS PERDOMO}

Otra persona influyente partícipe de estos negocios del azúcar fue Gaspar Álvarez de Miranda, natural de Gáldar (Gran Canaria), notario del secreto (16031628), receptor (1629-1630) y regidor. Álvarez de Miranda había vendido a Luis Perdomo 100 arrobas de azúcar, a 40 reales la arroba, de la cosecha de 1618 del ingenio de Guía. ${ }^{61}$ El azúcar lo recibió, por cuenta de Perdomo, Gregorio Méndez de Pedrosa, quien, según dijo, sólo fue intermediario y se encargó de venderlo a dos mercaderes flamencos de Las Palmas (de entre los cuales se nombra a Juan Jure) al precio de 34 reales la arroba, recibiendo su equivalente en ropa. A pesar de esa diferencia, Perdomo esperaba sacar beneficio, vendiendo la ropa y también, en parte, pagando con ella salarios; pero, según dijo, no obtuvo más que 3.000 reales, habiendo perdido tanto en el azúcar como con la ropa. ${ }^{62}$

No pudiendo pagar, Perdomo se vio con sus bienes embargados y sin crédito, por lo que aceptó, por indicación de Bernardino de Serpa, notario de secuestros, y «por mandado del S[eño]r Inqq[uisido]r Lobo», obligarse de nuevo con Álvarez de

\footnotetext{
58 Gonzalo Messía Lobo fue nombrado Inquisidor de México en 1623 (AlbERro, 1988: 83), pero debió de arreglárselas para dilatar su incorporación a ese tribunal, seguramente por sus intereses en Canarias. Medina (1991: 197) dice que tomó posesión el 17 de octubre de 1625, falleciendo al día siguiente. 59 Sentencia de 28 de febrero de 1630. AHN, Inq, leg ${ }^{\circ} 1814,6$ E.

60 AMC, Inq, xx-12, fo 525.

61 «De la haza q[ue] llaman el Drago», AMC, Inq, CxIX-44, fo 50.

62 «Que esta d $[i c]$ ha ropa con otras cosas q[ue] llevo para la dha fabricacion fue repartiendo en veces entre los oficiales y trabajadores del $\mathrm{d}[i c]$ ho ingenio al precio $\mathrm{q}[u e]$ podia concertarse con ellos $[\ldots] \mathrm{y}$ ansi se me fueron muchos dellos sin pagarle a este y ansi no pudo dexar de tener mucha perdida», idem, fo 55. Gregorio Méndez Pedrosa, hacendado y comerciante, alcalde que fue de Agaete, aparece en numerosas actividades relacionadas con la producción del azúcar en el noroeste de Gran Canaria.
} 
Miranda. ${ }^{63}$ Según escritura firmada en diciembre de 1619, Perdomo le vendía 400 panes de azúcar, 266 de azúcar blanco y 134 panes de azúcar de suertes, «a entregar en el tendal esta zafra $\mathrm{q}[u e]$ viene de 1620 en el ing[eni $]^{\circ}$ de Arucas». ${ }^{6}{ }^{4}$ Se concertó que se pagaría cada forma, lo mismo de azúcar blanco que de sorteado, a catorce reales, y las panelas que procedieran del dicho azúcar, al precio que convinieran. El azúcar se purgaría a costa y riesgo de Álvarez de Miranda, comprometiéndose Perdomo a darle «casa aparte buena y segura donde los purgue, andamios, furos y vasijas donde se eche la miel y el barro necesario». De 5.600 reales que importaban esos 400 panes de azúcar, Álvarez de Miranda entregaría 3.000 en el momento de la firma de la escritura, y los 2.600 restantes se los pagaría en ropa en el curso del mismo mes de diciembre. ${ }^{65}$ Ello le permitiría fabricar de nuevo el ingenio y pagar su deuda. Aparentemente, a la deuda por las 100 arrobas de azúcar, se añadía otra de 5.600 reales. En realidad, según Perdomo, los 3.000 reales al contado no los recibió, sino que se hizo figurar así lo que en verdad vino a ser el pago de las 100 arrobas de azúcar vendidas por Álvarez de Miranda en 1618. Éstas importaban 4.000 reales, pero de ellos había que restar 1.400 reales que Álvarez de Miranda percibió de Raton, quien las debía a Perdomo; una más de las incontables transferencias de deudas que complican estos casos.

Llegado mayo de 1620, cuando el azúcar estaba «en el tendal», Perdomo no hizo entrega a Miranda de los 400 panes; según diría, porque molía con labradores de medias y el concierto con ellos era partir en pilleras, después de limpio y purgado a costa del arrendatario del ingenio, lo que no sucedería hasta el mes de agosto. Por ello, Luis Perdomo se obligó por nueva escritura y contrato a entregar el azúcar en pilleras «limpio y sin riesgo» y a costa suya, sin que Miranda tuviese que pagar cosa alguna. Se estipuló que por la prórroga había de pagar al final de la zafra, el día del peso, «a quinze por ciento por los intereses y provechos del $\mathrm{d}[i c]$ ho açucar». Para la nueva escritura, que no se otorgó ante notario, hizo de «tercero» don Pedro Sarmiento, alguacil mayor del Santo Oficio, en cuyas manos quedó el escrito. ${ }^{66}$

El 29 de agosto de 1620 Gaspar Álvarez de Miranda manifestó ante el Tribunal que Luis Perdomo había terminado el peso del azúcar en el ingenio, había entregado a los labradores la parte que les correspondía, «y la q[ue] le quedó la va vendiendo y disipando», sin entregarle los 400 panes de azúcar. Pidió por ello que se diese mandamiento de embargo del azúcar obtenido que le hubiese correspondido a Perdomo, como así se decretó. ${ }^{67}$

63 Que le dijo Bernardino de Serpa «q[ue] si quería este vender quatrocientos panes de açucar a raçon de a quatorce reales por pan en formas con sus procedidos, $\mathrm{q}[u e]$ el sabía quien los pagara y dello pagaria la deuda $\mathrm{q}[u e]$ debia a Gaspar Alvarez y $\mathrm{q}[u e]$ el resto daría en ropa y dineros, y ansi este declarante como andaba afligido por no tener con $\mathrm{q}[u e]$ pagar hiço quenta $\mathrm{q}[u e]$ esperaba buena çafra de molienda y q[ue] con ello tendría con q[ue] pagar lo qual no fue como pensaba». AMC, Inq, cxIx-44, $\mathrm{f}^{\mathrm{o}} 54 \mathrm{v}^{\mathrm{o}}$.

64 Ante Andrés Rosales, escribano público, en 5 de diciembre de 1619. Idem, fs. 3 y ss.

65 AMC, Inq, CXIX-44, f $53 \mathrm{v}^{\circ}$.

$66 \mathrm{AHN}$, Inq, leg ${ }^{\circ} 1814,8$, fo 5, a 9 de mayo de 1620. Así, «por el procedido» de cada 100 panes de azúcar de los 400 que estaba obligado a entregar en el tendal, y que no se habían entregado, daría además 15 panes de refinado («de mieles batidas», se dice en otro lado) y 7 barriles de miel.

$67 \mathrm{El} 4$ de septiembre de 1620, en la casa de pilleras del ingenio, el alguacil mayor del Santo Oficio 
Luis Perdomo alegaría «lesión» y engaño. En primer lugar, como hemos adelantado, aducía que los puntos contenidos en la escritura otorgada en diciembre de 1619 no se habían cumplido, aunque él hubiese firmado que sí, ${ }^{68}$ pues ni había sido cierto el recibo de los 3.000 reales, ni se le dio ropa por el valor de los otros 2.600 reales. Añadía que el pago de 14 reales por cada pan se debía entender sin los procedidos, que tendrían de valor 6 reales, y por tanto cada pan, junto con ellos, debía valorarse en 20 reales «a justa y común estimación», no en 14: «que son de engaño y lesion seis r [reale]s en cada forma y asi todas las $\mathrm{d}[\mathrm{ic}]$ has cantidades se han de bajar y rebatir allanandome como me allano a bajadas y rebatidas entregalle lo que importare el verdadero precio». ${ }^{69}$ En esa complicada madeja de operaciones se sentía engañado, y por ello pedía al Tribunal que se anulara la escritura.

Naturalmente, otra era la argumentación de Álvarez de Miranda y de los suyos. En respuesta a Perdomo, el secretario, además de mantenerse en su alegato principal, exponía otros argumentos, algunos de los cuales tienen algún interés por lo que se refiere a las prácticas vigentes en la actividad azucarera. Venía a decir que Perdomo solía obtener buenos beneficios con el trueque del azúcar por ropa y su posterior negociación, de modo que si lo había hecho «fue por su comodidad y provecho»; que no recibió lesión ni daño, aún en caso de que de cada pan se sacasen 6 reales de procedidos, porque el costo de purgarlos y el peligro de perderlos y abatirse muchos de ellos era muy ordinario y corría por cuenta suya (de Miranda), por lo cual era muy justo el contrato; y que -lo que nos introduce en una cuestión «técnica» y en una posible forma de picaresca en el negocio- Luis Perdomo mandaba a su maestre que no llenase las formas en la manera en que se acostumbraba, sino con una cantidad de azúcar menor, «y asi [...] la mayor parte de los açucares [...] pesaron a seis y a siete panes en cada peso siendo lo mas ordinario pesar a tres y a quatro y lo mas largo a cinco cada peso de dos arrobas». ${ }^{70}$

El contador Cachupín testificó a favor del secretario, sosteniendo que el concierto con Álvarez de Miranda había sido de mucha utilidad para Perdomo, porque estaba sin crédito y sin él no habría podido continuar con la hacienda e ingenio; y afirmando, con razonamientos y cálculos propios de quien conocía muy bien el negocio, que no había habido «lesión». Estimaba que los 266 panes de azúcar blanco, «pesando todo a cinco, como es $\mathrm{p}[u ́ b l i]^{\mathrm{co}} \mathrm{q}[u e]$ asi peso», hacían 106 arrobas, y los 134 panes de escumas, pesando a seis en peso, 44 arrobas, lo que

embargó y puso en depósito 752 panes de azúcar, así como 23 balsas y 12 sinos de panela, que era la parte que le cupo a Perdomo de los cañaverales que había molido. AHN, Inq., lego 1814, 8, fo 13.

68 En realidad, el finiquito no lo firmaba él, sino, significativamente, don Pedro Sarmiento, alguacil mayor de la Inquisición, y Bernardino de Serpa, notario de secuestros, según se decía a petición de Luis Perdomo, por no saber éste firmar.

69 AMC, Inq, CXIX-44, fo 24.

70 Idem, $\mathrm{f}^{\circ} 50 \mathrm{v}^{\mathrm{o}}$. Perdomo lo negaba, y decía que si había habido algunos pesos de 6 o 7 panes, sería al final del peso del cañaveral que compartía con los labradores, informándonos de paso de otra práctica, «y es $\mathrm{q}[u e]$ como ban pesando y igualando los pesos con texas para pagarse unos a los otros [los distintos cultivadores] y enterarse es menester hacer peso de dos arrobas y media y a veces de tres». Idem, $\mathrm{f}^{\circ} 55 \mathrm{v}^{\circ}$. 
sumaban, juntadas, 150 arrobas, que vendidas a 40 reales -«como el açucar corre oy»-, serían 6.000 reales; más 1.200 reales de las mieles («lo que da cada forma de provecho son tres reales»), supondría que «todo el provecho» sería de 7.200, a los que habría que restar 300 reales entre gastos de purgar el azúcar (270 reales) y acarreo (30 reales). Quedarían líquidos 6.900 reales, de modo que descontándole los 5.600 que se le habrían prestado, le quedarían de ganancia a Luis Perdomo, según él, 1.300 reales, «conforme lo q[ua $]^{1}$ no fue leso ni engañado». ${ }^{71}$ Hacían piña con el secretario Álvarez de Miranda, pues, el notario de secuestros, el contador, el alguacil mayor y uno de los dos inquisidores, Messía Lobo.

Muy distinta fue la actitud del otro inquisidor, Juan Franco de Monroy (1610-1622). Una carta suya al Consejo, antológica por lo que se refiere al tema que tratamos, comienza con una frase lapidaria y terminante: «La Inquiss $[i c i]^{\text {on }}$ de Can[ari $]^{a}$, de poco aca, es un ingenio de azucar». ${ }^{72}$ Tenía el contrato que el secretario había hecho aceptar a Perdomo «por injusto, ilícito, y reprobado y ser muy peligroso en el fuero de la conciencia, y por cierto que como tal debe rescindirse y annullarse». Así lo había hecho constar en su voto, pero la causa se elevó a la Suprema en discordia, porque el otro inquisidor, Messía Lobo, votó a favor de los intereses del secretario. Según Franco advertía, el contrato había dado mucho que hablar en la ciudad y había "parecido a todos muy mal que ministros de la Inquiss $[i c i]^{\text {on }} \mathrm{y}$ oficiales del secreto abarquen tanto, sin perdonar ganancia ni cossa alguna, y que a un hombre cuitado y del campo que no sabe leer ni escribir» lo hubiesen forzado y engañado. Perdomo, en efecto, era, como hemos repetido, analfabeto, a pesar de la cuantía de los tratos en que participaba. El inquisidor Franco informó también al Consejo, a modo de antecedentes, de otros pleitos en que Miranda había estado metido, como un proceso contra el propio Perdomo y Gregorio Méndez de Pedrosa en 1609; u otro presunto atropello judicial cuya víctima había sido un bachiller Delgado, clérigo presbítero vecino de Tenerife, su padre y hermanos, «cuyos bienes y hacienda está poseyendo». ${ }^{73}$ Continuaba diciendo que, de acuerdo con lo establecido en instrucciones y cartas acordadas, los ministros del Santo Oficio deberían servir sus oficios como correspondía, ${ }^{74}$

71 Idem, fo 52. Exponía Cachupín «que el peso ordinario que suele haber en los ingenios es el blanco a cuatro y a cinco y las escumas a cinco y a seis». Cada peso, u operación de pesar, solía ser de dos arrobas, de modo que de los 266 panes, si entraban cinco en cada peso, salían 53 pesos, que a 2 arrobas cada uno hacían 106 arrobas. Respecto a las escumas, 134 darían para 22 pesos, que a 2 arrobas/ peso harían 44 arrobas. Si en cada «peso» entraban 5 panes de azúcar blanco, ello suponía que cada pan pesaría unos 4,5 kilos de media. Sobre el peso de los panes de azúcar, véanse Lово (1989: 62), quien establece 5 kg./pan; y Gambín (2008: 281 y ss.). En una subasta de panes de azúcar embargados a Gerónimo Raton, 159 panes pesaron 62 arrobas y 21 libras, lo que venía a ser 4,5 kg/pan; pero en otra realizada el mismo día, 111 panes pesaron 36 arrobas (3,7 kg/pan), si bien es cierto que en este caso el depositario urgía su venta porque decía que se estaba «todo perdiendo y abatiendo», y quizás por eso en cada pesada de 2 arrobas entraban 6 o 7 panes, AMC, Inq, xxxI-35. En el pleito más arriba referido entre Cachupín y Bartolomé López aparecen otros ejemplos de pesos de a cuatro o cinco panes en el ingenio de Marcos de León en Telde hacia 1605, AMC, Inq, CL-8.

72 AHN, Inq, leg ${ }^{\circ} 1814-8,3$ de noviembre de 1620.

73 Ibidem.

74 En principio, estaba prohibido a los ministros asalariados del Santo Oficio «por sí ni por otra persona, directe ni indirecte [...], entender en tratos o mercaderías en cualquier manera que sea» (JIMÉNEZ, 1980: 248). Las Instrucciones eran leídas en voz alta al comenzar cada año, presentes todos los oficiales 
o si no dejarlos; «y por mi fe que es esto lo que conviene»-venía a proponer. El inquisidor Franco se sentía solo entre enemigos -«me aborrecen como al mismo demonio»-; por no sumarse a los negocios de sus colegas o al menos hacer la vista gorda: «la vivienda es un infierno, en no quitando la capa a los v[ecino]s y dándola a los de cassa». ${ }^{75}$

Entre los que habían recibido azúcares del ingenio de Arucas había varios mercaderes extranjeros, uno de los cuales era Henry Isham, jefe de facto de la comunidad británica de Tenerife. Otro era el flamenco Jorge Offlaque, a quien el Tribunal ordenó mantener en depósito el azúcar que Perdomo le había entregado, y que había sido embargada a petición de Álvarez de Miranda. En 1621 Messía Lobo recibió de Offlaque, a cuenta del azúcar depositado en él, cierta cantidad de dinero que Luis Perdomo -no sabemos por qué- debía a este inquisidor. Miranda, en tanto que acreedor, autorizó que, manteniéndose el embargo sobre lo demás, se pudiese pagar a Messía; y el propio secretario también recibió de Jorge Offlaque varios miles de reales a cambio de las panelas embargadas en su poder. ${ }^{76}$ Otros acreedores menos privilegiados debieron esperar a que la causa se sustanciase.

El inquisidor Messía Lobo, a petición de Álvarez de Miranda, nombró administrador de la hacienda embargada, para que continuara en explotación, a Juan González, sacristán de Arucas. La documentación manejada indica que la intervención le servía a Lobo, como mínimo, para hacer o pagar favores. ${ }^{77}$ En 1624 se dice que del trigo que pertenecía a Perdomo y que estaba depositado, el inquisidor Lobo mandó dar a labradores para sembrar. En la cuenta de la cosecha obtenida se hace referencia a «lo que le cupo» al inquisidor, en lo que parece un beneficio suyo. ${ }^{78}$ Se trataba de tierras de la hacienda de Arucas que algunos declararon haber sembrado «de medias con el Inq[uisido]r Lobo». ${ }^{79}$ Los documentos (billetes y libranzas) firmados por Lobo lo fueron, inequívocamente, a título personal, no del Tribunal. ${ }^{80}$

Entre las triquiñuelas practicadas por el secretario Álvarez de Miranda figuraba la de hacer que otros acreedores de Luis Perdomo le cedieran las deudas que éste tenía con ellos, o comprarlas por una cantidad inferior, ${ }^{81}$ operaciones que, más allá del posible beneficio, lo dejaban a su merced: «para hacerme molestias y vexaciones y causarme prisión [...], como persona poderosa y mi acreedor [...]

en la sala del Tribunal.

75 AHN, Inq, leg ${ }^{\circ} 1814-8$.

76 Recibí de Gaspar Álvarez de Miranda de 17 de septiembre de 1620, AHN, Inq, lego 1815, 8. Finiquito con la firma «Ldo. Messia Lobo» de 28 de enero de 1621. AMC, Inq, CLVIII-11, $\mathrm{f}^{\circ} 284$.

77 En un billete de su puño y letra, de 29 de agosto de 1622 y dirigido al dicho administrador, se lee: «con esta va el mandam $[i e n] \mathrm{t}^{\mathrm{o}} \mathrm{p}[a r]^{\mathrm{a}} \mathrm{q}[u e]$ el sr. Ju${ }^{\circ} \mathrm{G}[$ onzá $][[e] \mathrm{z}$ reparta las tierras de labor [...]. El sr. $\mathrm{T}[$ enie $] \mathrm{n}^{\text {te }}$ me ha dicho $\mathrm{q}[u e]$ quisiera sembrar ahí $4 \mathrm{f}[$ anega $] \mathrm{s}$, yo estimare mucho $\mathrm{q}[u e]$ a el y al sr. alcalde de ese lugar los acomode en muy buena parte y [...] al sr. Man[ue]l Alv[are]z y su hijo el alg[ua] $\mathrm{c}[i] l$ mayor [...]. El Dr. P $[e d r]^{\circ}$ Sarmiento [alguacil mayor del Santo Oficio] me ha dicho q[ue] tomará alg[una $]$ s tierras de las $\mathrm{q}[u e]$ se han de dar arrendadas fuera de riego, tambien recibire placer se les acomoden en buena parte [...]». AMC, Inq, CLVIII- $11, \mathrm{f}^{\mathrm{o}} 8$.

78 AMC, Inq, II-26, fo 11.

79 Idem, $\mathrm{f}^{\circ} 16$.

80 AMC, Inq, CLVIII-11.

81 AMC, Inq, CLXXIV-50, CXLVIII-24. 
aunq[ue] le constaba de mi pobreza e imposibilidad compro la $\mathrm{d}[i c]$ ha deuda [...]»-se quejaba Perdomo- ${ }^{82}$ Un ejemplo: como más arriba se dijo, en 1620 Luis Perdomo se obligó ante escribano público a pagar 6.341 reales que habría recibido de Mateo Delgado. ${ }^{83}$ En marzo de 1621 concertó un nuevo préstamo, de 2.000 reales, que pagó en agosto entregando a Delgado, en el ingenio, 50 arrobas de azúcar, a $40 \mathrm{rs} /$ arroba. Delgado puso pleito a Perdomo ante el teniente de gobernador por supuesto impago de esa deuda, alegando que los 2.000 reales que confesaba haber recibido eran a cuenta de una deuda mayor anterior. Álvarez de Miranda se hizo ceder esa deuda de 2.000 reales por parte de Mateo Delgado, pidiendo ejecución contra Perdomo por esa cantidad. Pero la justicia acabó por dar por probado el pago de la deuda, y entonces Miranda se volvió contra Delgado para reclamarla, recurriendo al Santo Oficio. Si ante el juez ordinario se identificaba como «regidor», en el Tribunal se presentaba como «secretario». Atendiendo a su petición, los inquisidores dieron mandamiento de ejecución contra los bienes de Mateo Delgado. ${ }^{84}$

Los inquisidores Santalis (1622-1628) y Rincón (1624-1628), unánimemente, reprocharon las maniobras del secretario Miranda, ordenaron al fiscal seguir causa contra él y acordaron informar al inquisidor general y al Consejo, «por el delito que a cometido en la compra de la $\mathrm{d}[i c]$ ha escritura siendo persona poderosa y en tiempo que» [Luis Perdomo] estaba «en inferior fortuna, embargados sus bienes y mandado prender»; «que todo agrava mas en ministro del S[an]to Off $[i c i]^{\circ}$ mayormente aviendo prosedido las $\mathrm{d}[i c]$ has deudas de cosas indecentes a su profesión». ${ }^{85}$

Los dos mismos inquisidores, sin embargo, disintieron cuando, dos años más tarde, Luis Perdomo, todavía en la cárcel, solicitó hacer información de pobreza para litigar ante el Consejo de la Inquisición. Las frases cruzadas entre ambos, que el notario recogió, revelaban un profundo enfrentamiento. Finalmente Santalis, como inquisidor más antiguo, remitió las informaciones a la Suprema con sólo su firma, pidiendo que la causa, que llevaba más de seis años en esa alta instancia, se despachara; y señalando la obstrucción que Álvarez de Miranda, con sus apoyos, había venido haciendo, «por quanto le esta mal que el pleito se vea por las culpas que de él resultan c[ontr $]^{\mathrm{a}}$ su persona». ${ }^{86}$

\section{LUIS PERDOMO Y LA HACIENDA DE ARUCAS DE DON MARTÍN CERÓN DE SANTA GADEA}

Como más arriba se dijo, Luis Perdomo había tomado en arrendamiento para los años de 1617 a 1623, «q[ue] son seis frutos alzados y cogidos», la hacienda del ingenio de Arucas, perteneciente a don Martín Fernández Cerón de Santa

82 AHN, Inq, leg ${ }^{\circ} 1814,8$.

83 Ver nota 45.

84 AMC, Inq, CLxxIv-50, fo 53 . Auto de 27 de abril de 1626. Uno de los dos firmantes era Martínez Pastor, que el año anterior había ascendido de fiscal a inquisidor.

85 Auto de 19 de abril de 1625. AHN, Inq, leg ${ }^{\circ} 1814,6$ C.

86 Ibidem. Carta al Consejo de 29 de enero de 1627. 
Gadea, vecino entonces de Sevilla, mediante contratos firmados, de la parte de la propiedad, por el fiscal Gabriel Martínez Pastor en virtud de la sustitución de poder que en su persona había hecho el inquisidor Pedro Hurtado de Gaviria, quien lo había recibido del propietario de la hacienda. ${ }^{87}$ En 1609 Fernández Cerón había concedido poderes al inquisidor Hurtado para que en su nombre tomase posesión del mayorazgo, ${ }^{88} \mathrm{y}$ al año siguiente lo apoderó para administrarlo. ${ }^{89}$ Al marcharse Hurtado de las islas, el poder se sustituyó en Martínez Pastor. ${ }^{90}$ A partir de entonces, esa importante propiedad estuvo de algún modo bajo la influencia y tutela de agentes inquisitoriales, ya el fiscal Martínez, ya, de modo menos claro, el inquisidor Messía.

En realidad, hubo dos períodos en el arrendamiento. En 1617, habiendo renunciado el arrendatario anterior, el fiscal, después del correspondiente pregón público, arrendó a Perdomo la hacienda -tierras de cañas, sementeras, aguas, ingenio, casas, etc.- por un tiempo de dos años, que se cumplirían por San Juan de 1619, al precio de 500 doblas cada año. El arrendatario estaba obligado a plantar a su costa tres suertes de cañas, cuyos frutos serían para el arrendador. Los reparos de que hubiese necesidad la hacienda y el ingenio los pagaría el arrendatario, pero se descontarían de las 500 doblas de la renta; y también pagaría Perdomo, descontándolos de ésta, todos los tributos con que la hacienda estaba cargada. Los citados gastos habían de ser expresamente autorizados por el fiscal Martínez, y pagados previas libranzas suyas. ${ }^{91}$ En 1619, al cumplirse el término del arrendamiento anterior, de nuevo se pregonó la renovación, pero esta vez concurrió frente a Perdomo otro aspirante, Miguel de Muxica Lezcano, alférez general y regidor perpetuo de la isla, quien manifestó querer tomar en arrendamiento la hacienda por un período de seis años, al precio de 550 doblas por año, comprometiéndose a plantar seis suertes de cañas y a dejar plantadas el último año tres suertes en beneficio de la propiedad..$^{92}$ Perdomo ofreció de renta 500 ducados por año, y aunque su oferta era algo inferior a la de Muxica, como Martínez reconoció, fue la preferida. El fiscal aducía que el alférez y regidor no era «persona llana de quien fácilmente se pueda cobrar la d[ic]ha renta», y que, por tener mucha hacienda, podía ser que desatendiera la del mayorazgo, lo que no era el caso de Perdomo. Quizás existían otras razones: Miguel Muxica estaba casado con Mariana de Ayala, heredera de Sofía de Santa Gadea..$^{93}$ Seguramente no convenía que el arrendatario fuese un personaje tan poderoso, próximo además

87 AMC, Inq, xxxvII-15, fo $222 \mathrm{v}^{\mathrm{o}}$.

88 El inquisidor, en efecto, tomó posesión del mayorazgo en mayo de 1609 (CABALLERO, 1973: 141).

89 Por poder otorgado en Cádiz el 28 de julio de 1610 encargaba a Hurtado de Gaviria la administración de la hacienda, cesando al que hasta entonces había sido su administrador, Francisco de Aguilar. AHPLP, PN 1064, fo 156 y ss.

90 Sustitución ante Juan de Quintana, escribano público, 6 de mayo de 1611. AHPLP, PN 1064, fo 162. 91 Escritura ante Francisco Delgado Salazar de 15 de octubre de 1617. AHPLP, PN 1064, fs. 162 y ss. Véase Anexo documental (11.3).

92 Postura hecha ante el gobernador, Fernando de Osorio, el 8 de abril de 1619. AHPLP, PN 1064, fo 155.

93 Miguel de Muxica aparece percibiendo, en nombre de su mujer, un tributo sobre la hacienda que los representantes de Cerón rechazaban. AMC, Inq, CxLVIII-24, fo 261 vo. 
por lazos familiares a los fundadores del mayorazgo. Mejor Perdomo, a quien se renovó el arrendamiento por cuatro años más. ${ }^{94}$ Incluso aunque, al parecer, no había cumplido con el pago de la renta.

En efecto, en 1623 Martín Cerón, a través de procurador, se querelló contra Perdomo por no haber satisfecho la renta y de resultas fue este preso en la cárcel pública; primero por la justicia ordinaria y luego por mandato del Tribunal, ante el cual se llevó la causa como consecuencia de sus conexiones con otras que ya veían los inquisidores..$^{95}$ Reclamaba la propiedad el pago de los 3.000 ducados correspondientes a la renta de los seis años de arrendamiento, y en su caso que se ejecutara esa cantidad sobre los bienes embargados. Perdomo alegaba que, para poderse ejecutar, era necesario que primero se hiciesen las cuentas de lo que habían importado los gastos forzosos realizados en la hacienda e ingenio, así como los tributos pagados; y sostenía que, al no haberlo hecho el juez ordinario de la isla, se lo había encarcelado indebidamente. Se quejaba igualmente de que el año de 1623, que correspondía a su arrendamiento, estando él en la cárcel, don Martín Cerón, «o las personas $\mathrm{q}[u e]$ su poder hubieron», se metieron a usar del ingenio sin que hubiese terminado el arrendamiento ni le hubiese sido requerido. ${ }^{96}$ Ese punto se añadía, como uno más, al resto de los elementos en litigio: Perdomo sostenía que no se había comprometido a pagar una cantidad líquida, sino la que correspondiese después de descontados los gastos realizados, por lo que pedía que se hiciese cuenta de ellos; la otra parte los rechazaba, al menos parcialmente, con distintas razones: que no habían sido necesarios, que no se probaban adecuadamente, que algunos de los tributos se habían pagado indebidamente, que no habían sido expresamente autorizados por Gabriel Martínez Pastor, etc.

El pleito se alargó durante siete años y no se resolvió hasta la llegada del inquisidor visitador Escobar del Corro. Éste aceptó el punto de vista de Perdomo y nombró contadores que revisasen las cuentas. La justificación de los gastos realizados durante los años del arrendamiento dio lugar a la presentación de un conjunto de memorias, relaciones, finiquitos, albalaes, etc., de gran interés para el estudio de las cuentas del ingenio. ${ }^{97}$ Martínez Pastor reconoció, conforme a lo pedido por Luis Perdomo, haber dado a éste «libranza general» para el pago de los tributos, es decir, que no era preciso autorizar individualizadamente el de cada uno de ellos, y que el conjunto de todos importaba, «antes de la reducción

94 Éstos correrían desde San Juan de 1619 hasta San Juan de 1623; Perdomo se comprometía a plantar a su costa cinco suertes de cañas, cuyo producto se partiría por mitades entre arrendador y arrendatario; los pagos de tributos y los gastos de reparaciones se atenderían en las mismas condiciones que en el arrendamiento anterior. Escritura notarial de 17 de abril de 1619. AHPLP, PN 1064, fs. 171 y ss. 95 Viéndose ya ante la Inquisición la causa que contra Luis Perdomo seguía Gaspar Álvarez de Miranda, y saliendo a dicho pleito otros acreedores pretendiendo ser preferidos, el Tribunal mandó acumular a aquélla la seguida ante la justicia ordinaria por don Martín Cerón contra el propio Perdomo, toda vez que unos y otros tenían pretensiones sobre unos mismos bienes. AMC, Inq, CXLVIII-24, fo $270 \mathrm{v}^{\circ}$. 96 Idem, fo 228. Inquisición, 23 de septiembre de 1624.

97 Sin contar los tributos pagados, Perdomo presentaba cartas de pago que en total sumaban para los cinco años de 1618 a 1622, ambos incluidos, 13.302 reales de gastos, cuyas partidas principales eran las de carpintería (6.446 rs.), herrería (2.443 rs.) y albañilería (1.782 rs.). AMC, Inq, xxxVIII-29, xxxVII-15, CLXVIII-43. 
de la nueva pragmática», 300 ducados cada año. ${ }^{98}$

Los contadores nombrados para revisar los gastos de la hacienda estimaron que, confrontado el importe de la renta que se había obligado a pagar Luis Perdomo con los gastos realizados por éste que se consideraron necesarios y que tocaban al arrendador, la hacienda resultaba deudora de 5.138 reales. ${ }^{99}$ Por una vez, parece que Luis Perdomo Betancor iba a ganar un pleito. Siete años después. Ante el inquisidor visitador.

\section{COMERCIAR CON EL ENEMIGO}

La vinculación de los agentes inquisitoriales con el mundo de los negocios quedó de manifiesto en Tenerife con ocasión de la guerra contra Inglaterra que comenzó en 1625, cuestión que estudié hace años (FAJARDO, 2000). Conviene recordar el asunto, porque tiene conexiones, que sólo ahora conocemos y podemos entender cabalmente, con lo que tratamos ahora en este artículo. Cuando en 1626 el Consejo de la Inquisición dio la orden de procesar a los ingleses herejes que hubiesen cometido delitos de fe, los inquisidores de Canarias no estuvieron de acuerdo acerca de cómo interpretarla. Mientras el inquisidor Santalis proponía proceder contra los herejes que residiesen en las Islas, hubiesen dado escándalo o no, los otros dos inquisidores, Rincón y Martínez Pastor, defendieron que sólo se hiciese en el caso de haber delinquido o dado escándalo después de la publicación del bando de guerra. Martínez sostenía «que desde que están en estas islas no ha resultado cosa de consideración contra los dichos ingleses y así es del parecer que no se innove nada». ${ }^{100}$ La discordia la transmitieron a la Suprema, la cual les ordenó -«aunque lo mandado estaba claro», advirtieron- hacer información acerca de cómo vivían los ingleses en materia de religión, pues era posible que algunos estuviesen fingiendo ser católicos; y que, resultando que antes del bando eran herejes, se podría proceder contra ellos, aunque no hubiesen delinquido después. Tampoco a la vista de esta carta hubo acuerdo entre los inquisidores de Las Palmas, porque alguno interpretó que se refería a los ingleses que después del bando acudían a las iglesias y recibían los sacramentos, pero «no habla de los que solamente son herejes y no han delinquido». Se trató el caso del mencionado Henry Isham, tenido por hereje y que después del bando había ido a misa y había dicho que siempre había sido católico. Santalis preguntaba por qué no se había procedido contra ningún inglés de los asentados en las Islas desde 1610, en que el Consejo ordenó que el capítulo que permitía a ingleses y escoceses estar en los reinos españoles por razones de comercio sólo se aplicase a los transeúntes; Martínez contestaba que en veintiocho años que llevaba en las islas, no había

98 AMC, Inq, xxVII-15, fo 222 vº. Declaración en 29 de enero de 1630. Esa elevada carga, procedente en gran parte del momento de la fundación del mayorazgo (CABALLERO, 1973: 61 y ss.), comprendía tributos a la fábrica catedral, al comunal de la Catedral, al Hospital de San Martín, al Hospital de San Lázaro, al convento de monjas de la Concepción Bernarda, al convento de San Pedro Mártir; así como a varias personas físicas, entre ellas la mencionada doña Mariana de Ayala.

99 AMC, Inq, XxVII-15, fo 221.

100 British Museum, Egerton ms., 1512. 
entendido que hubiese habido herejes avecindados, lo que venía a ser una interpretación favorable a los ingleses del concepto de avecindamiento. En el caso particular de Isham, frente a la opinión de Santalis, los otros dos inquisidores impusieron su parecer de que después de haberse declarado católico no había delinquido, y por tanto no había motivo para proceder contra él. Es evidente que había dos voluntades punitivas diferentes, relacionadas probablemente con la mayor o menor integración de los inquisidores en la sociedad canaria, y quizás con sus negocios. Sobre si embargar o no las mercancías de los comerciantes ingleses también hubo, inicialmente, discrepancias, porque, mientras Santalis insistía en los embargos, Rincón se inclinaba por dejar ese cometido a los jueces reales. Finalmente se impuso el criterio de Santalis, que era el inquisidor más antiguo, encomendándose a Martínez, entonces de visita en Tenerife, realizar y coordinar las actuaciones necesarias. Martínez no demostró entusiasmo por el encargo que se le hacía, contestando que en Tenerife no había ingleses herejes, sino sólo tres o cuatro reducidos que estaban casados; que no entendía que la Inquisición pudiera proceder contra mercancías de contrabando; y que él estaba muy ocupado con la visita. El Tribunal insistió, pero las actuaciones inquisitoriales tuvieron muy poca eficacia. Como no se fiaba de sus ministros, para hacer las diligencias en un determinado pueblo, encargaba que se enviara a los comisarios o notarios de otra localidad distinta. Desde Las Palmas, los inquisidores ordenaron visitar la casa del comisario del Santo Oficio en Garachico y embargar las mercancías que en ella se encontrasen. Pero pocas mercancías inglesas se hallaron, ni en esas manos ni en otras, porque los agentes inquisitoriales no guardaron el secreto debido y hubo tiempo para esconderlas. Por supuesto, en el comercio prohibido con los ingleses participaban desde el gobernador y muchos de los regidores de Tenerife hasta el comisario de La Laguna y el alguacil mayor del Santo Oficio, ambos «señores de vinos».

\section{EL TRIBUNAL, VISITADO}

La implicación de oficiales de la Inquisición de Canarias en negocios y tratos no siempre limpios, las irregularidades cometidas de que se ha tratado, el intento de encubrirlas, su denuncia por parte de otros ministros y el consiguiente enfrentamiento entre ellos; todos estos hechos, o algunos de ellos, debieron de dar lugar al envío en 1628 de un inquisidor visitador, Juan Escobar del Corro. El Consejo de la Inquisición debió de tener conocimiento de la enemistad entre los inquisidores canarios por diferentes vías, empezando por las cartas e informes que ellos mismos enviaban. En noviembre de 1626 el fiscal, Francisco Manso Dávila, se dirigía al Tribunal haciendo un llamamiento para que hubiera entre sus miembros la «conformidad» que las instrucciones exigían, «no dando ocasion a murmuraciones y escandalo, como le ay en esta ciudad, viendo no ay en el la paz y concordia que es raçon»; y amenazaba con avisar de tales comportamientos, 
si no se corregían. ${ }^{101}$ No sabemos si lo hizo.

La visita era un instrumento de carácter extraordinario para la inspección y el control de los tribunales de distrito. Generalmente motivadas por quejas o denuncias llegadas a la Suprema acerca de abusos o desórdenes, las visitas se hacían, por eso mismo, sin ninguna periodicidad determinada. Para su realización, el Consejo enviaba a un inquisidor visitador, procedente de otro tribunal, quien inspeccionaba las instalaciones, examinaba el estado del archivo, visitaba las cárceles y tomaba declaración a todos los presos, comprobaba el estado de la hacienda e interrogaba al conjunto de los funcionarios y servidores. Aplicaba un Interrogatorio de 49 preguntas establecido para tales inspecciones que indagaba en la vida y el comportamiento profesional de cada uno de los oficiales. Se leía un pregón público invitando a declarar a cuantas personas quisieran hacerlo, y también se llamaba después a otras. La visita se cerraba con la redacción de un informe en el que se recogían los cargos que se hacían a cada uno de los ministros.

La Inquisición de las islas Canarias recibió en el siglo XVI tres visitas de inspección: respectivamente, las de los inquisidores Bravo de Zayas (1574-1575), Luis Gortáçar (1582-1583) y Claudio de la Cueva (1592-1597). La primera de ellas corresponde a un momento de reorganización del tribunal, a los pocos años de haberse independizado del de Sevilla; la de Gortáçar es la única de las visitas cuyo motivo conocemos: el enfrentamiento, de dominio público, que había entre los dos inquisidores; De la Cueva continúa el fortalecimiento del aparato inquisitorial, aún muy precario, y la corrección de irregularidades y abusos. ${ }^{102}$ De la visita de Escobar -la última que se hizo al tribunal insular- nada sabíamos, aparte de su existencia; ${ }^{103}$ y no mucho más podemos hoy añadir. Lo que de ella conocemos procede de las breves referencias contenidas en una relación cronológica sobre la Inquisición de Canarias que va desde sus comienzos hasta el año de 1656, y que da noticias, sobre todo, de los sucesivos inquisidores. En ella se apunta que Escobar fue nombrado visitador en marzo de 1628, que tomó posesión de su cargo el 30 julio de ese año, y que «la visita que hiço fue informar a los señores del Consejo sin açer cargo ni escribir». ${ }^{104}$ De los tres inquisidores que había entonces en las Islas se dice en el mismo documento que fueron visitados por Escobar; del inquisidor Santalis se afirma que «fue llamado al Consejo y después fue restituido a su plaça», y que murió «en tiempo de la visita»; mientras que de Rincón y de Martínez Pastor se escribe que se jubilaron. Nada más. En los libros de registro de los nombramientos del personal de la Inquisición aparece que el 6 de noviembre de 1628 el inquisidor general despachó el título de jubilación de los inquisidores Alonso Rincón de Ortega y Gabriel Martínez Pastor, así como el del secretario Gaspar Álvarez de Miranda. ${ }^{105}$ Los tres, el mismo día. Estas jubilaciones eran

101 «De no lo cumplir asi protesto dar quenta para que se ponga el remedio que conviene». ES 35001 AMC/INQ-308.025.

102 Sobre las visitas de inspección realizadas a la Inquisición de Canarias, ANAYA y FAJARDO (1985-1987 y 1991); у Acosta (1992).

103 Millares (1874: III, 51 y IV, 156) lo menciona como visitador en 1629, pero no añade más.

104 AMC, Inq, CX-16, fo $11 \mathrm{v}^{\circ}$.

105 Registro de Cámara del Inquisidor General Zapata. Castilla. AHN, Inq, libo 371, fs. $28 v^{\circ}-29$.

Vegueta, 21 (1), 2021, 407-441. eISSN: 2341-1112 
inequívocamente el resultado de una caída en desgracia; ${ }^{106}$ por cuanto el tribunal de Canarias era uno «de entrada», es decir, que de aquí se pasaba normalmente a otros más cotizados. En 1611 el inquisidor general había decidido subir los salarios de los oficiales del Santo Oficio en las islas, «en recompensa del destierro $\mathrm{q}[$ ue $]$ los ministros del pasan»;107 pero, aún así, su importe era la mitad -y lo mismo sucedía con las ayudas de costa- que en los tribunales peninsulares, ${ }^{108}$ sin duda como consecuencia de la pobreza del tribunal isleño.

De todo ello se concluye que Escobar no realizó una visita en forma, ni redactó un informe de la misma -«sin açer cargo ni escribir»-, pero dio cuenta de lo que vio. La Suprema debió de optar por remover a la cúpula corrupta del tribunal de Canarias, sin llegar más lejos. Las líneas dedicadas a Santalis dan la impresión de que este inquisidor no recibió la misma reprobación que sus compañeros; pero no podemos asegurarlo, pues sólo sabemos que falleció en 1628 en el ejercicio de su cargo.

\section{CONCLUSIONES}

Los casos estudiados muestran a un buen número de miembros del Santo Oficio dedicados a actividades que les estaban expresamente vedadas por las Instrucciones. Cristóbal Cachupín, contador del Tribunal durante casi tres décadas, fue dueño de cañaverales, participó en la producción azucarera solo o en compañías, arrendó ingenios y, a propósito de tales actividades, se enfrentó a otros interesados, algunos de ellos miembros del Cabildo, del clero y de la propia Inquisición. Denunciado por la tala ilegal del monte, el Tribunal, para defenderlo, entró en confrontación con la justicia real ordinaria.

Gaspar Álvarez de Miranda, natural de la isla y regidor de ella lo mismo que Cachupín, fue secretario del Santo Oficio durante un cuarto de siglo. Aparece implicado en tortuosos tratos con distintas personas, y en particular con Gerónimo Raton y con Luis Perdomo Betancor; respaldado, generalmente, por la mayoría de los oficiales inquisitoriales.

Sobre la figura y las ocupaciones del flamenco Gerónimo Ratton, personaje no desconocido de los historiadores canarios de este período, la documentación consultada aporta datos inéditos. También es novedosa, pensamos, la información sobre la explotación de la hacienda e ingenio del mayorazgo de Martín Cerón en Arucas, arrendados en este período a Luis Perdomo; individuo apenas conocido que parece haber sido víctima y quizás instrumento de más de uno de los servidores del Tribunal.

Entre ellos se cuenta el inquisidor Messía Lobo, quien realizaba negocios por

106 Álvarez de Miranda fue nombrado receptor un año después. Idem, f $155 \mathrm{v}^{\mathrm{o}}$. Sin embargo, hay que recordar que se trataba de un seglar, al margen del cursus honorum de los inquisidores. Sin que podamos excluir otro tipo de razones.

107 AHN, Inq, lib ${ }^{\circ}$ 587, fo 41. Libro 16 de Castilla.

108 Ver, para el período estudiado, AHN, Inq, libs. 584 y subsiguientes (Libros de Castilla 13 y siguientes); y libs. 361, 366, 368, 369 y 371 (Registros de Cámara de los inquisidores generales). 
cuenta propia y otros, por lo que parece, amparándose en su sobrino Rodrigo Messía, con Raton y con Perdomo, beneficiándose a título personal del embargo de los bienes de Perdomo y de la intervención por parte del Tribunal de la hacienda de Arucas.

Gabriel Martínez Pastor, servidor también del Tribunal durante un cuarto de siglo, como fiscal y, finalmente, como inquisidor, fue administrador del mayorazgo de Arucas. Entre otras operaciones más o menos lícitas, tuvo relaciones con Perdomo y con Raton; y en tanto que acreedor de este último se enfrentó judicialmente con el inquisidor Messía Lobo.

Oficiales de segundo nivel fueron partícipes de esos hechos, como sucedió con don Pedro Sarmiento, alguacil mayor, Bernardino de Serpa, notario de secuestros, y Lorenzo de Zurita, receptor.

Los inquisidores Franco, Santalis y, de modo menos rotundo, Rincón censuraron y denunciaron a sus colegas o subordinados, entendiendo que sus acciones eran fraudulentas, abusivas y, en cualquier caso, absolutamente contrarias a los comportamientos exigidos por las ordenanzas del Santo Oficio. Tales irregularidades, así como la persistencia de los enfrentamientos intestinos, llevaron al Consejo de la Inquisición al envío de un inquisidor visitador, de cuya inspección resultó la sustitución de la cúpula del Tribunal.

En resumen, las causas civiles y criminales examinadas ponen en evidencia un conjunto de prácticas ilícitas y corruptas: uso del cargo para lucrarse, abusos de poder, parcialidad e intercambio de favores, nepotismo, extorsiones, destrucción u ocultación de documentos, utilización en beneficio propio de la jurisdicción inquisitorial y del estatuto privilegiado de sus miembros. La asociación de los oficiales inquisitoriales con determinados vecinos y el enfrentamiento con otros; la hostilidad entre los propios miembros del Santo Oficio; los choques jurisdiccionales en defensa de intereses particulares; incluso la lenidad o la negligencia en la labor inquisidora, no pudieron por menos que dar escándalo y dañar la imagen de la institución, comprometiendo y perjudicando su actividad y funcionamiento.

Quizás las características propias de algunos sectores de la economía canaria -y por encima de todos de la producción azucarera, inseparable de distintos instrumentos financieros y del tráfico mercantil- propiciaban la realización de operaciones especulativas que podían producir rápidos beneficios. La participación del personal inquisitorial en actividades que en principio les estaban prohibidas podría verse justificada por la cortedad de sus retribuciones, lo que en el caso de Canarias era más cierto, sin que les acompañase un nivel medio de los precios igualmente bajo. Posiblemente existía una cierta tolerancia mientras no hubiese demasiado ruido o los abusos fuesen flagrantes; y seguramente había una mayor indulgencia con los oficiales laicos del Tribunal. La discreta dedicación de los oficiales del Santo Oficio a faenas lucrativas probablemente fue mucho más frecuente de lo que recogen y reflejan los documentos; pues por su naturaleza judicial éstos sólo nos hablan de las situaciones de conflicto, no de la pacífica cotidianidad.

Una observación pertinente es la de que la intervención en los negocios 
requería un cierto grado de integración en la sociedad local. Esto daría ventaja a los insulares, y es evidente el peso de determinados ministros, pertenecientes a familias influyentes y con largas carreras en el Tribunal, de lo que son ejemplos el receptor Lorenzo Zurita, el notario de secuestros Bernardino de Serpa, o los sucesivos miembros de la familia Sarmiento, que ostentaron durante varias generaciones el cargo de alguacil mayor. Pero también participaron los foráneos, como es el caso de los inquisidores Messía Lobo y Martínez Pastor, este último con un dilatado curriculum en el archipiélago. La presencia de los oficiales inquisitoriales en el entramado institucional, como dignidades catedralicias en el caso de los eclesiásticos, o como regidores en el de los legos, incrementaría, por descontado, su influencia.

Sería necesario saber si los comportamientos referidos en este trabajo fueron algo excepcional, o se trataba de usos arraigados en la sociedad insular; hasta qué punto, en su caso, desdelos órganos superiores se vigilaron y corrigieron desafueros y desmanes; y cómo cambió todo ello a lo largo del tiempo, si es que lo hizo. En el estado actual de la investigación no estamos en condiciones de responder a tales cuestiones. Nuestro conocimiento acerca del personal inquisitorial, su extracción social, su reclutamiento, sus trayectorias, sus actividades y su relación con los poderes locales es aún manifiestamente insuficiente.

\section{REFERENCIAS}

Acosta GonzÁlez, A. (1992): «La Inquisición canaria entre 1574 y 1576. La decisiva visita de inspección del doctor Bravo de Zayas», Anuario de Estudios Atlánticos, 38: $17-71$.

Alberro, S. (1988): Inquisición y sociedad en México, 1571-1700, Fondo de Cultura Económica, México.

Alemán Ruiz, E. (2014): «Algunas circunstancias del acceso al oficio de Regidor en la Isla de Gran Canaria en el siglo XVII», en F. MorAles (coord.), Actas del X Coloquio de Historia Canario-Americana, Cabildo Insular de Gran Canaria, Las Palmas de Gran Canaria: 593-605.

AnAya Hernández, L.A.; FajARdo spínOla, F. (1985-1987): «Oposición a la Inquisición, conflictos y abusos de poder a fines del siglo XVI (las visitas de inspección a la Inquisición canaria)», El Museo Canario, 47: 217-239.

ANAYA HERNÁNDEZ, L.A.; FAJARDO SPÍNOLA, F. (1991): «Las visitas de inspección a la Inquisición de Canarias. Siglo XVI», en F. Morales (coord.), Actas del VIII Coloquio de Historia Canario-americana (1988), vol. II, Cabildo Insular de Gran Canaria, Las Palmas de Gran Canaria: 775-801.

Andújar castillo, F., Feros carrasco, A. y Ponce leiva, P. (2017): «Corrupción y mecanismos de control en la Monarquía Hispánica: una revisión crítica», Tiempos modernos: Revista Electrónica de Historia Moderna, vol. 8, n 35: 284-311. Brito GonzÁlez, A. (2002): Los extranjeros en las Canarias orientales en el siglo XVII, Cabildo Insular de Cran Canaria, Las Palmas.

Caballero Mújica, F. (1973): Pedro Cerón y el Mayorazgo de Arucas, Ediciones del 
Ayuntamiento de Arucas, Arucas.

Caro Baroja, J. (1968): El Señor Inquisidor y otras vidas por oficio, Alianza Editorial, Madrid.

Cioranescu, A. (1958): «Escritores canarios», Revista de Historia Canaria, 123-124: 292-295.

Fajardo Spínola, F. (2000): «Comerciar con el enemigo. Canarias y la guerra contra Inglaterra (1625-1630)», en F. Morales (coord.), Actas del XIII Coloquio de Historia Canario-Americana (1998), Cabildo Insular de Gran Canaria, Las Palmas de Gran Canaria: 1927-1944.

Fajardo Spínola, F. (2003): Las víctimas del Santo Oficio. Tres siglos de actividad de la Inquisición de Canarias, Gobierno de Canarias/Fundación de Enseñanza Superior a Distancia, Las Palmas de Gran Canaria.

FigueroA, J. (1963): «Léxico de la caña de azúcar en Palmira y La Cumbre (Valle del Cauca, Colombia)», Thesaurus, Boletín del Instituto Caro y Cuervo, 18 (3): 553-621.

Gambín García, M. (2008): El Ingenio de Agaete: oro dulce en Gran Canaria a comienzos del siglo Xvi: las cuentas de la Hacienda (1503-1504) y otras noticias de la época (1480-1517), Oristán y Gociano Editores, Santa Cruz de Tenerife.

Inchaurbe y Aldape, Fr. D. de (1996): Noticias sobre los provinciales franciscanos de Canarias, Instituto de Estudios Canarios, La Laguna.

JimÉNEZ MONTESERÍn, M. (1980): Introducción a la Inquisición Española. Documentos Básicos para el estudio del Santo Oficio, Editora Nacional, Madrid.

Lobo Cabrera, M. (1989): Monedas, pesas y medidas en Canarias en el siglo XVI, Ediciones del Cabildo Insular de Gran Canaria, Las Palmas de Gran Canaria.

Martín Santiago, F.E. (2013): «El apellido Ratón en Gran Canaria», Revista Digital Cuarto de Apero, 30 de septiembre de 2013.

Medina, J.T. (1991): Historia del tribunal del Santo Oficio de la Inquisición en México, Consejo Nacional para la Cultura y las Artes, México.

Millares Torres, A. (1874): Historia de la Inquisición en las Islas Canarias, Imprenta de La Verdad, Las Palmas.

Morales Padrón, F. (1974), Ordenanzas del Concejo de Gran Canaria (1531), Cabildo Insular de Gran Canaria, Las Palmas de Gran Canaria.

PANIZO SANTOS, J.I. (2014): «Aproximación a la documentación judicial inquisitorial conservada en el Archivo Histórico Nacional», Cuadernos de historia moderna, 39: 255-275.

SÁenz Berceo, M. del C. (1998): «La visita en el tribunal del Santo Oficio de la Inquisición de Valladolid (1600-1650)», Revista de la Inquisición, 7: 333-388.

Torres SANTANA, E. (1991): El comercio de las Canarias orientales en tiempos de Felipe III, Cabildo Insular de Gran Canaria, Las Palmas de Gran Canaria. 


\section{ANEXO DOCUMENTAL}

\section{1. Concierto entre Marcos de León y Cristóbal Cachupín para moler caña. AHN, Inq, $\operatorname{leg}^{\mathrm{o}} 1815.2$, fols. $117 \mathrm{v}^{\mathrm{o}}-120$.}

[f $\left.\mathrm{f}^{\mathrm{o}} 117 \mathrm{v}^{\mathrm{o}}\right]$ Decimos nos Marcos de Leon $\mathrm{r}[\mathrm{e}] \mathrm{g}[i]^{\text {dor }}$ desta isla de Can[ari $]^{\mathrm{a}}$ y Xr[istó $]$ val Cachupin contador del Santo Off $[i c i]^{\circ}$ de la Inquisicion destas islas que por quanto yo Marcos de Leon tengo un ingenio de moler cañas de asucar en el barranco de Telde que en tiempo antiguo fue de $\mathrm{Dy}[\mathrm{eg}]^{\circ}$ de Surita e yo el $\mathrm{d}[i c]$ ho $\mathrm{Xr}[$ istó $]$ val Cachupin tengo en esta siudad de Telde muchas cañas de asucar de planta y socas para molerlas [ $\mathrm{f}^{\mathrm{o}} 118$ ] el año venidero de mil y seissientos y sinco estamos convenidos y consertados de que yo el $\mathrm{d}[\mathrm{ic}]$ ho Marcos de Leon se las e de moler en la forma e con las condisiones siguientes.

Primeramente yo el $\mathrm{d}[i c]$ ho Marcos de Leon me obligo por esta escript $\mathrm{t}^{\mathrm{a}}$ a moler a el $\mathrm{d}[i c]$ ho $\mathrm{Xr}$ [istó]val Cachupin onse suertes de cañaverales de asucar que tiene en esta siudad de Telde suyas y agenas ansi de planta como de socas las $\mathrm{q}[\mathrm{u} a]$ les le molere y comensare a molerlas por todo el mes de henero del $\mathrm{d}[i c]$ ho año de mil y seissientos y sinco en el $\mathrm{d}[i c]$ ho mi ingenio para lo qual me e de prevenir de leña y mantenim $[i e n]^{\text {tos }} \mathrm{y}$ de toda la gente neses[ari $]^{a}$ para ello sin que falte cosa alguna y e de tener el $\mathrm{d}[i c]$ ho ingenio aderesado y moliente y corriente ansi de cassa de prensas como de calderas e cobres e todo muy cumplido para el beneff $[i c i]^{\circ}$ y molienda de los $\mathrm{d}[i c]$ hos cañaverales e le e de dar offisiales suffisientes de cassa de calderas ansi maestro escumero y tachero e calderero de melar e los demas offisiales que suelen andar en las $\mathrm{d}[i c]$ has cassas de calderas y ansimesmo le e de dar cassa de purgar y de reffinar y purgador y reffinador para reffinar las mieles que prosedieren del $\mathrm{d}[i c]$ ho asucar e todas las formas que obiere menester para el $\mathrm{d}[i c]$ ho asucar y escumas y reffinados e los signos e tinas para las panelas e tanque para la remiel y el barro neses[ari $]^{\circ}$ de suerte que para la molienda de los $\mathrm{d}[i c]$ hos cañaverales ansi en el ingenio como en cassas de purgar y de reffinar e de poner segun esta $\mathrm{d}[i c]$ ho todos los pertrechos neses $[a r i]^{\text {os }}$ en tal manera que el $\mathrm{d}[i c]$ ho $\left[\mathrm{f}^{\mathrm{O}} 118 \mathrm{v}^{\mathrm{o}}\right]$ asucar e reffinados no les falte cosa alguna para su beneff $[i c i]^{\circ}$ y si alguna falta obiere que por ella le venga algun daño a el $\mathrm{d}[i c]$ ho $\mathrm{Xr}$ [istó]val Cachupin se la pagare con mi perssona e bi [en $]^{\text {es }}$ que para ello obligo por lo qual el d[ic]ho $\mathrm{Xr}$ [istó]val Cachupin me a de dar e pagar por cada tarea de las que moliere setesientos reales de plata castellanos por cada tarea de ocho calderas de a sesenta y sinco cubos cada caldera y todo lo que montare a este respeto me lo a de pagar tres meses despues que se acabe la $\mathrm{d}[\mathrm{ic}]$ ha molienda y le e de resibir en quenta dello las partidas que me fuere dando que constare por mis firmas y por su libro del $\mathrm{d}[i c]$ ho $\mathrm{Xr}[i s t o ́]$ val Cachupin las $\mathrm{q}[u a]$ les $\mathrm{d}[i c]$ has cañas que tiene se las comensare a moler por el mes de henero del año venidero como esta $\mathrm{d}[i c]$ ho y se las proseguire hasta averlas acabado sin entremeter cañaveral ninguno en ellas sin voluntad del $\mathrm{d}[i c]$ ho $\mathrm{Xr}$ [istó]val Cachupin porque ansi estamos consertados de se las moler y ansimismo me obligo que las casas de purgar y reffinar estaran cubiertas con sus andamios y tinglados y furos y con sus puertas e llaves para que el $\mathrm{d}[i c]$ ho $\mathrm{Xr}$ [istó]val Cachupin tenga la guardia e custodia con su asucar que pretende de suerte que toda esta molienda a de ser a mi costa sin que el d[ic]ho Xr[istó] val Cachupin gaste de su bolsa cossa alguna hasta que este el asucar puesto en pilleras salvo los $\mathrm{d}[i c]$ hos setesientos reales que me a de dar por cada tarea como esta $\mathrm{d}[i c]$ ho e todo el asucar e bugangas e mieles batidas e reffinados e panelas e remieles que prosedieren de los d [ic] hos cañaverales [ $\mathrm{f}^{\circ} 119$ ] lo a de llevar el $\mathrm{d}[i c]$ ho $\mathrm{Xr}$ [istó] val Cachupin para si mesmo como cossa suya propia sin que yo aya ni tenga en ello cossa ni $\mathrm{p}[a r]^{\text {te }}$ alguna porque con averme pagado los $\mathrm{d}[i c]$ hos setesientos $\mathrm{r}[\text { eale }]^{\mathrm{s}}$ por cada tarea en la forma $\mathrm{d}[\mathrm{ic}]$ ha abra cumplido con su obl[igaci $]^{\text {on }}$. 
Iten es condision que el $\mathrm{d}[i c]$ ho $\mathrm{Xr}$ [istó]val Cachupin me a de dar tres mil formas poco mas o menos que tiene en el ingenio de don Gregorio del Castillo por el presio que le an costado que paresera por su libro y ansimismo un parol de cobre que tiene en el $\mathrm{d}[i c]$ ho ing $[e n i]^{\circ}$ en lo $\mathrm{q}[u e]$ le costo e pago por el a Damian Hernandes calderero e ansimesmo me a de dar sien cargas de leña buena que tiene cortadas en El Lance poco mas o menos pagandole lo que es costumbre pagar por cada una ques a seis reales menos quartillo cada carga y otras quinientas cargas de leña de alamo que tiene en La Angostura a seis quartos cada carga de corte y otras dusientas y sinquenta cargas de sabse e alamo que tiene en el valle de Caseres a real cada una de corte e ansimismo me a de dar setesientas cargas de leña de asebuche en el monte de Lantiscal de que tiene lic [enci $]^{\mathrm{a}}$ del $\mathrm{Cab}[i \mathrm{ild}]^{\mathrm{o}}$ para las cortar pagandole setesientos y setenta y sinco reales que dio a la çiudad por la lic [enci ${ }^{\text {a }}$ dellas e me a de trespasar la $\mathrm{d}[i c]$ ha lic $[\text { enci }]^{\mathrm{a}}$ para que yo las corte todas las quales $\mathrm{d}[i c]$ has partidas de leña e formas e parol e de recibir en quenta de la $\mathrm{d}[i c]$ ha maquila que me a de pagar como esta $\mathrm{d}[i c]$ ho o si dellas obiere mas cantidad $\left[\mathrm{f}^{\mathrm{o}} 119 \mathrm{v}^{\circ}\right]$ tambien se lo resibire en quenta e si menos tanto menos abre $\mathrm{r}\left[\right.$ ecibid ${ }^{\text {do }}$ por manera que con todo abra quenta e razon con las quales $\mathrm{d}[i c]$ has condisiones yo Marcos de Leon me obligo de moler al $\mathrm{d}[i c]$ ho $\mathrm{Xr}$ [istó] val Cachupin las $\mathrm{d}[i c]$ has onse suertes de cañaverales como esta $\mathrm{d}[i c]$ ho sin que en ello aya dilasion ni falta alguna todo a mi costa e minsion sin que de su parte gaste cossa alguna salvo los $\mathrm{d}[i c]$ hos setesientos reales por cada tarea.

$\mathrm{Y}$ ansimesmo es condision que los asucares que prosedieren de los $\mathrm{d}[i c]$ hos cañaverales se an de llevar a la cassa de purgar y encabalgarse en los andamios e irlos benefisiando luego sin que se pierda punto en ello. E yo el d[ic]ho $\mathrm{Xr}$ [istó]val Cachupin que a todo lo que d[ic] ho es e estado presente digo que asepto esta escript $t^{a}$ e la instipulasion della e me obligo de que llevare a moler las $\mathrm{d}[i c]$ has cañas al $\mathrm{d}[i c]$ ho ing $[e n i]^{\circ} \mathrm{del} \mathrm{d}[i c]$ ho Marcos de Leon para que el susod $[i c]$ ho me las muela en su ing $[e n i]^{\circ}$ en la forma $\mathrm{d}[i c]$ ha y que le pagare por cada tarea de las que moliere a razon de los $\mathrm{d}[i c]$ hos setesientos reales e le dare la leña formas y paroles según esta $\mathrm{d}[i c]$ ho $[\ldots]\left[\mathrm{f}^{\circ} 120\right]$ fecha la carta en Telde ques en Gran Can[ari ${ }^{a}$ lunes dies y seis del mes de mayo de mil y seis sientos y quatro a[ño $]^{\text {os }}[\ldots]$.

\section{2. Autos de la Real Audiencia acerca de las personas que cortaron y talaron los montes circunvecinos a la ciudad de Telde. AMC, Inq, XXXVI-9, s. fol ${ }^{\circ}$.}

En la siudad de Telde [...] en veynte y quatrodias del mes de enero de mil y seysientos y nueve a $[\tilde{n}]^{\text {os }} \mathrm{P}[e d r]^{\circ}$ Ponse executor de la Real Aud[ienci $]^{\mathrm{a}}$ destas islas [...] hizo parecer ante si a Felipe Baez labrador v[ecin $]^{\circ}$ de la dha siudad [...] y preguntado por el auto de la Real Aud[ienci $]^{\text {a }}$ dixo que [...] de todo el tiempo que aquel se acuerda que tiene uso de razon a esta parte no a visto semejante destruicion y talas como las que se han $\mathrm{f}[\mathrm{ec}] \mathrm{ho}$ de ocho dias [sic] o mas a esta parte porque en tiempos atras que este $\mathrm{t}[\mathrm{estig}]^{\circ}$ conocio por señores de yngenios a el lic[encia]do Castillo y a Diego Diaz de la Garsa y Agustin Yngles y otras personas los susod[ic] hos se prevenian para hazer sus moliendas e safras de leña que trayan e hazian traer de tras la isla donde no se resebia perjuicio alguno y tambien la trayan de fuera desta isla en nabios con lo qual los montes y montañas della y v [ecin $]^{\text {os }}$ no resebian el daño que an resebido y resiben del tiempo que tiene declarado aca porque este $\mathrm{t}[\text { estig }]^{\circ}$ ha visto que arredor deste pueblo de Telde en toda la redonda an cortado mas de media legua de montes que abia del servisio de los v $\left[\right.$ ecin ${ }^{\text {os }}$ que son en el Draguillo y en las montañas de Ayga y barranco de Silva ques lo mas lejos media legua desta siudad y quarto 
de legua y a partes menos y esta tala que se a hecho y hase en el valle de Caseres es desde el lugar todo lo qual no solam $[e n]^{\text {te }}$ lo cortan pero lo an ydo y van arrancando de rrais y de forma que jamas volvera y las tierras que an ydo y van talando son tierras toda la mayor parte dellas que no sirven para otra cosa que para crear los $\mathrm{d}[i c]$ hos montes el qual servia para el servisio de la siudad y provim $[e n]^{\text {to }}$ de leña del y para gasto de los ganados en que que an resebido y resiben los $\mathrm{v}[\mathrm{ecin}]^{\mathrm{os}}$ muy grande y muy notable daño y perjuicio en ello y esta tala y talas an hecho del $\mathrm{d}[i c]$ ho tiempo de dies a[ñ $]^{\text {os }}$ a esta parte Gaspar de Ayala y Marcos de Leon y de presente lan ydo haciendo y prosiguiendo y prosigue hasta el dia de oy $\mathrm{Xr}$ [istó]val Cachupin persona que tiene a renta el ingenio de Gregorio del Castillo en el qual ha visto este $\mathrm{t}[\mathrm{estig}]^{\mathrm{o}}[\ldots]$ que tiene mucha y muy gran cantidad de leña cortada en el yngenio de que va haciendo su safra y sabe asimismo que en el barranco de las Goteras [...] y en el lomo de Peña y la sima que dizen y malpayses de Xinamar a cortado y arrancado de rrais como tiene $\mathrm{d}[i c]$ ho muy grande cantidad de leña el $\mathrm{d}[i c]$ ho $\mathrm{Xr}$ [istó]val Cachupin $[\ldots]$ de que como tiene $\mathrm{d}[i \mathrm{ic}]$ ho es tanto el perjuicio que resiben los $\mathrm{v}[\mathrm{ecin}]^{\text {os }} \mathrm{y}$ criadores $[. .$. porque de ordinario los v $[e c i n]^{\text {os }}$ deste lugar para el provim $[e n]^{\text {to }}$ de leña cada un dia podian dar dos y tres caminos de leña para el servisio de sus casas y a el presente si no es irla a buscar al monte Lantiscal questa distante de media legua y a otras partes mas desta siudad no la hallan [...] y ha venido a tal y tan grande destruision las talas que se an hecho y hazen que arredor desta siudad de Telde abia cantidad de higueras canarias de que se sustentaba y aprovechaba gente pobre sin hazer daño a nadie como cosa que estaba fuera de eredades las quales se an talado y arrancado que de presente no se halla ninguna fuera de eredad $[\ldots]$ y firmolo y es de set $[e n t]^{\mathrm{a}}$ años $[\ldots]$.

Luis Lopes Perdomo labrador v[ecin $]^{\circ}$ de la siudad de Telde [...] preguntado al tenor del

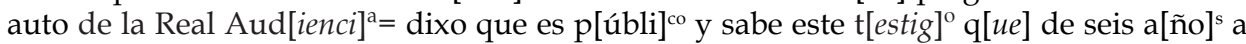
esta parte que Marcos de Leon y Xr[istó]val Cachupin tienen los ingenios de la siudad an talado y arrancado de todo punto los montes circunvezinos de esta siudad de Telde como son el valle de Caseres y barranco de las Goteras umbria y solana Hoya de Niebla umbria del Barranco Seco de una parte y otra umbria de la Higuera Canaria hasta las eredades del valle de Caseres ensima de la Higuera Canaria montaña de Hayga el barranco de Silva el Draguillo el barranco de la Madre del Agua e todos los sauzes que en ella abia e ter $[m i]^{\text {no }}$ de Xinamar todos los quales $\mathrm{d}[i c]$ hos montes que ansi an talado los susod[ic] hos y arrancado de rais seran mas cantidad de dosientas fanegadas de tierra la qual dexaron de todo punto limpia y tal que los $\mathrm{v}[\mathrm{ecin}]^{\mathrm{os}}$ no se pueden aprovechar della por ser tierra inutil y de ningun provecho para sementeras y que no produsira ni dara otra cosa alguna que lo que daba que era el monte que le an cortado y es tanto el daño y perjuicio que dello a resultado queste $\mathrm{t}[\text { estig }]^{\circ}$ no se atreve a determinarlo y le parece que abran sacado mas cantidad de $\mathrm{t}[\text { reint }]^{\mathrm{a}}$ mil cargas de leña y la mayor parte $\mathrm{Xr}$ [istó]val Cachupin y sabe que totalmente padesen los ganados por aber talado los $\mathrm{d}[i c]$ hos montes y los $\mathrm{v}[e c i n]^{\text {os }}$ desta siudad porque valiendo como valia una carga de leña seis quartos les cuestan agora por irse a buscar lexos dos $\mathrm{r}[e a l e]^{\mathrm{s}}$ y sabe que hasta unas higueras canarias que abia en el contorno desta siudad de que se valian los $\mathrm{v}[\mathrm{ecin}]^{\mathrm{os}}$ pobres las an cortado y arrancado y quemado en los ingenios, orovales y tajinastes, ques de donde las abejas se sustentaban [...] y asta unos asebuches y otros arboles de $\mathrm{q}[\mathrm{ue}]$ se aprovechaban los $\mathrm{v}[\mathrm{ecin}]^{\mathrm{os}} \mathrm{p}[\mathrm{ara}]^{\mathrm{a}}$ aperos, los han cortado de forma $\mathrm{q}$ a menester ir a la montaña de Oramas y a otras $\mathrm{p}[\mathrm{ar}]^{\text {tes }}$ tres o quatro leguas a buscarla [...]. 
11. 3. Escritura de arrendamiento del ingenio de Arucas. Extracto. AHPLP, PN n ${ }^{\circ}$ 1064 , fols. $162-167 \mathrm{v}^{\mathrm{o}}$.

$\left[\mathrm{f}^{\mathrm{o}}\right.$ 162] Sepan quantos esta carta vieren como yo el $1[\text { icencia }]^{\mathrm{do}}$ Gabriel Martinez Pastor arcediano de Fuerteventura en la Catedral destas yslas de Can[aria $]^{\mathrm{a}}$ y fiscal del Santo Oficio de la Inquisicion della en nombre y en vos de don Martin Fernandes Seron de Santa Gadea Uarte y en virtud del poder que del susodicho tengo que me sustituyo el señor doctor don Pedro Hurtado de Gaviria inquisidor que fue en este d[ic]ho Obispado y a el presente es del Reino de Granada la qual sustitucion paso ante Juan de Quintana escr[iban $]^{\circ}$ $\mathrm{pu}[\mathrm{blic}]^{\mathrm{co}}$ desta isla en seis días del mes de mayo del año pasado de mil y seis sientos y onze y el poder del dicho don Martin Fernandes Seron se otorgo en la siudad de Cadiz en veinte y ocho dias del mes de julio de mil y seis sientos y dies años [...] otorgo y conosco por esta presente carta que digo que por quanto teniendo en arrendamiento Pedro Gonsales de Ayala la hazienda y mayorasgo de Arucas pertenesiente a el dicho don Martin Fernandes Seron ques el ingenio tierras y aguas [...] por estar imposibilitado de poder fabricar la dicha $\left[\mathrm{f}^{\mathrm{O}} 162 \mathrm{v}^{\mathrm{o}}\right.$ ] hazienda y cumplir el dicho arrendamiento se aparto del [...] y por mi parte se pidio ante la just $[i c i]^{\mathrm{a}}$ ordinaria desta isla se mandase traer en pregon el dicho ingenio tierras y aguas y lo demas anejo y perteneciente a la dicha hazienda para que si hubiese alguna persona que la quisiese tomar en arrendamiento paresiese a hacer postura porque a el que mas diese por ella se le diese y [...] paresio Luis Perdomo vecino de la villa de Arucas e hizo postura de dar en cada año quinientas doblas de a quinientos maravedis cada una moneda desta isla en el qual se hizo remate por el dicho arrendamiento por no aber otro mayor ponedor [...]. Por tanto en la mejor via y forma que aya lugar en el dicho nombre y usando de los dichos poderes otorgo que arriendo y doy en arrendamiento a el dicho Luis Perdomo que presente esta el dicho ingenio quel dicho don Martin Fernandes Seron tiene y posee en el dicho termino de Arucas con todo lo a el anejo y pertenesiente y casas de morada ques lo que se contiene en el ynbentario que pasa ante el presente escr $[i b a n]^{\circ}$ con todas las tierras y aguas que a poseydo [ $\mathrm{f}^{\mathrm{o}} 163$ ] y posee el dicho don Martin Fernandes Seron pertenesientes al vinculo y mayorasgo que instituyeron Pedro Seron Capitan general que fue desta isla y doña Sofia de Santa Gadea su mujer a favor del dicho don Martin Seron ansi tierras de cañas como de pan sembrar que se especifican en el dicho ynbentario el qual a de asetar en esta escritura ademas del entrego que se le a fecho por ante el presente escr [iban $]^{\circ}$ el qual dicho arrendamiento lo hago conforme a el dicho remate que fue por el tiempo de dos años y precio en cada uno dellos de quinientas doblas los quales an comensado y comiensan a correr y se cuentan desde el dia de San Juan de junio prosimo pasado deste presente año por manera que an de ser dos moliendas y dos fructos alsados y cogidos que se cumpliran por el día de señor San Juan del año de mil y seis sientos y dies y nueve con que las sementeras y millo que estubieren por coger las a de alsar y gosar el dicho Luis Perdomo y a de de ser obligado a pagar las dichas quinientas doblas en fin de cada un año por manera quel primero a de pagar por el dia de señor San Juan de junio del año que viene de mil y seis sientos y dies y ocho y dellas a de pagar los tributos que en cada un año se pagan sobre la dicha hazienda en virtud de las libransas que yo diere y a el mesmo plaso a de ser la renta del segundo y ultimo año y lo que sobrare despues de pagados los [ $\mathrm{f}^{\mathrm{O}} 163 \mathrm{v}^{\mathrm{o}}$ ] dichos corridos y los reparos que aqui iran espesificados me lo a de pagar a mi o a la persona que lo ubiere de aber en nombre del dicho don Martin Fernandes Seron en dineros de contado [...] con que ademas de ello a de ser obligado el dicho Luis Perdomo a plantar en la dicha hazienda tres suertes de cañas en las tierras que disen de San Sebastian que son de la dicha hazienda dos suertes en esta tierra y la otra en el cercado de Ariñez para lo qual el susodicho a de ser obligado a hazer arar las dichas tierras de las rejas que son nesesarias para cañas y poner la planta y hazer todos los demas costos que sean 
nesesarios hasta aberlas plantado sin que por ello se descuente del dicho arrendamiento cosa alguna porque con esta condision y grabame hizo el dicho remate y e de benefisiar ansimesmo a mi costa y minsion las dichas tres suertes de cañas de todos los benefisios que sean nesesarios las quales e de plantar dos dellas el año que biene de mil y seis sientos y dies y ocho y la otra el año de mil y seis sientos y dies y nueve y la ultima suerte a de benefisiar solamente hasta aber cumplido este arrendamiento y por rason de lo susod[ic] ho le doi todas las cañas que oy estan en ser que son las contenidas en el dicho ynbentario sin reservar ningunas para quel susodicho durante el dicho arrendamiento gose de sus [ $\mathrm{f}^{\circ}$ 164] frutos para si como cosa suya propia [...] y el fruto destas e de gosar yo en nombre de mi parte y de los demás frutos que dellas prosedieren y el dicho arrendamiento le hago con las condisiones siguientes. Primeramente que se le a de dar al dicho Luis Perdomo el dicho ingenio moliente y corriente como es costumbre con todos los pertrechos que tiene y se contienen en el dicho ynbentario que esta fecho, y acabado el dicho arrendamiento lo a de volver a entregar moliente y corriente en la forma y orden que lo resibe y con todas las cosas y pertrechos que se contienen en el dicho ynbentario y todo lo que se ubiere de hazer $\mathrm{y}$ fuere nesesario para poner el dicho ingenio moliente y corriente y aderesar las casas de purgar y otros gastos nesesario para ello a de ser con mi ynterbension o de la persona que para ello yo nombrare con mi poder y lo que se gastare se a de descontar del dicho arrendamiento. Yten es condision que todos los reparos y adobios que se ofresieren hazer en el dicho ingenio durante el tiempo del dicho arrendamiento a de ser a costa del eseto que todos los [ $\mathrm{f}^{\mathrm{o}} 164 \mathrm{v}^{\circ}$ ] gastos y reparos que fueren nesesarios hasta cantidad de doze reales y de ay para abaxo todos ellos an de ser por quenta del dicho Luis Perdomo y la cantidad que fuere menester de doze reales arriba a de ser por quenta del dicho arrendamiento como es uso y costumbre en semehantes arrendamientos [...]. Yten que durante el dicho arrendamiento el dicho Luis Perdomo a de ser obligado a su costa y minsion a acudir a todo el gasto que le tocare para las asequias y repartidores y asequieros y obras de cal que se ofresieren y solamente se a de descontar del dicho arrendamiento en los dichos dos años quinientos reales y todo lo demas lo a de suplir y pagar el dicho Luis Perdomo para un horno de cal. Yten es condision que e de haser quemar la bagasera questa en el dicho ingenio por el riesgo que se corre lo qual hare poner por obra ynviando persona con la gente y agua nesesaria para que con mas comodidad se pueda quemar y cumplido el dicho arrendamiento el dicho Luis Perdomo la a de dejar quemada a su costa y minsion y que para seguridad deste arrendamiento y paga del y de lo demas a que se obliga el dicho Luis Perdomo a de dar por fiadores a Manuel [ $\mathrm{f}^{\circ}$ 165] Alvarez y a Damian Hernandes vecinos de Arucas los quales se an de obligar de mancomun insolidum [...] y con estas condiciones le doi el dicho ingenio en el dicho arrendamiento con todas las dichas tierras y aguas y lo demas que se contiene en el dicho inbentario por el dicho tiempo de dos años [...] durante el qual obligo a el dicho don Martin Fernandes Seron y a sus bienes a que no le quitaran el dicho arrendamiento hasta aberse cumplido por venta ni renta ni en otra manera [...]. Y es condision que abiendose cumplido el dicho arrendamiento si la dicha hazienda se ubiere de arrendar en virtud del dicho poder obligo a el dicho don Martin Fernandes [ $\mathrm{f}^{\mathrm{o}} 165 \mathrm{v}^{\circ}$ ] Seron que por el tanto se la dara a el dicho Luis Perdomo dandole la siguridad que da aora y la que fuere menester. $Y$ es condision que si el dicho Luis Perdomo en estos dichos dos años plantara en las tierras de la dicha hazienda algunas cañas de mas de las dichas tres suertes que esta obligado a plantar para la dicha hazienda el susodicho a de gosar del fruto dellas para si con que pague la renta del tiempo que tuviere ocupadas las dichas tierras despues que se cumpliere el dicho arrendamiento por el presio cada suerte de tierra y agua de como meresiere en el dicho termino. E yo el dicho Luis Perdomo que presente estoy a esta escritura otorgo que la aseto e resibo en mi la estipulasion y validasion della sigun y de la manera questa dicho por el dicho señor Licen[cia ${ }^{\text {do }}$ don Grabiel Martines arcediano 
de Fuerteventura y resibo de su merse en el dicho nombre el dicho ingenio tierras y aguas del mayorasgo de Arucas [...] [ $\left.\mathrm{f}^{\circ} 166\right]$ [...] con el cargo de plantar las dichas tres suertes de cañas a su tiempo y sason y lo mesmo he de hazer los beneficios necesarios y si no las plantare y hiziere los dichos beneficios que a mi costa el dicho señor fiscal o otra persona en su nombre del dicho don Martin Fernandes Seron las pueda mandar plantar y benefisiar a el mayor presio que hallare y por lo que costare me pueda executar [...] y pagare las dichas quinientas doblas a el plazo y plasos aquí espesificados y en la forma quel dicho señor arsediano lo declare y guardare y cumplire todas las condisiones y obligaciones desta dicha escritura so las penas en ella puestas [...] y cumplido el dicho arrendamiento entregare el dicho ingenio moliente y corriente sigun y de la manera que lo resibo y dare las dichas [ $\mathrm{f}^{\mathrm{O}}$ $166 \mathrm{v}^{\circ}$ ] fianzas y para siguridad de todo lo que aqui me obligo ypoteco por espresa y espesial ypoteca todos los frutos que prosedieren de la dicha hazienda durante este arrendamiento $[\ldots]\left[167 \mathrm{v}^{\circ}\right][\ldots]$ fecha la carta en Can[ari $]^{\mathrm{a}}$ en quinse días del mes de otubre de mil y seis sientos y dies y siete años estando en las casas de la morada del dicho señor arcediano y los otorgantes que yo el presente escr[iban $]^{\circ}$ doy fe que conosco y son los contenidos lo firmaron [...]. Paso ante mi Bartolome Carrillo del Castillo escr[iban $]^{\circ}$ p[úbli] $]^{\circ}[\ldots]$. 
